\title{
Mid-Ordovician and Late Devonian magmatism in the Togtokhinshil Complex: new insight into the formation and accretionary evolution of the Lake Zone (western Mongolia)
}

\author{
Igor SOEJONO ${ }^{*}$, David BURIÁNEK¹, Martin SVOJTKA², Vladimír ŽÁČEK¹, Pavel ČÁP', \\ Vojtěch JANOUŠEK'
}

${ }^{1}$ Czech Geological Survey, Klárov 3, 11821 Prague 1, Czech Republic; igor.soejono@geology.cz

${ }^{2}$ Institute of Geology of the Czech Academy of Sciences, Rozvojová 269, 16500 Prague 6, Czech Republic

* Corresponding author

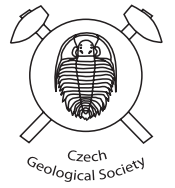

New field, petrographic, geochemical and geochronological data from the Togtokhinshil Complex (western margin of the Lake Zone, Central Asian Orogenic Belt) reveal the presence of two separate Early Palaeozoic magmatic pulses: Mid-Ordovician and Late Devonian. The Mid-Ordovician (c. $460 \mathrm{Ma}$ ) magmatism produced various types of mafic plutonic rocks (gabbro-diorite suite) emplaced into the volcanosedimentary sequence of the Baatar Fm. Gabbros to gabbrodiorites have metaluminous and mostly low to normal-K calc-alkaline or possibly tholeiitic character. The majorand trace-element as well as Nd isotopic signatures suggest its magmatic-arc geotectonic setting and imply the derivation either exclusively from the mantle or in part from the juvenile mafic crust.

The Late Devonian (c. $376 \mathrm{Ma}$ ) granite suite intruded the rocks of both the gabbro-diorite suite and the Baatar Fm. Granites are subaluminous and have a high-K calc-alkaline to shoshonitic character. Their magmatic arc-like geochemical signature is interpreted as inherited from the recycled arc-related crustal source. The granite suite seems a product of extensive mantle heat-induced crustal anatexis. The Depleted Mantle Nd model ages (c. $0.75 \mathrm{Ga})$ indicate derivation of the magmatic rocks of the both suites from relatively juvenile, and geochemically immature, sources.

These results provide a clear evidence of the Mid-Ordovician arc-related magmatism in the western part of the Lake Zone. They thus prolong the assumed period of magmatic-arc activity and constrain onset of accretionary processes in this part of the Central Asian Orogenic Belt. The gabbro-diorite suite represents either part of a long-lived magmatic-arc or, more likely, a member of multiple island-arc system along the western margin of the Lake Zone. Newly described Late Devonian magmatism in the Togtokhinshil Complex provides further evidence of tectono-thermal event that was widespread in the Central Asian Orogenic Belt. The geodynamic cause for this event remains uncertain, but effects of lithospheric thinning and/or asthenospheric mantle upwelling are considered the most likely.

Keywords: Central Asian Orogenic Belt, Lake Zone, magmatism, U-Pb zircon dating, geochemistry

Received: 16 October, 2015; accepted: 26 January, 2016; handling editor: O. Gerel

The online version of this article (doi: 10.3190/jgeosci.208) contains electronic supplementary material.

\section{Introduction}

The formation and evolution of the Central Asian Orogenic Belt (CAOB; Şengör et al. 1993) is still not completely understood and the nature of its individual parts has been studied by number of researchers. Several models of the CAOB evolution have been proposed; however, the basic idea of subduction-accretion processes (Şengör et al. 1993; Badarch et al. 2002; Xiao et al. 2004; Windley et al. 2007; Kröner et al. 2010) is broadly accepted. The accretionary history of the western Mongolian part of the CAOB was related to the Late Proterozoic to Early Palaeozoic formation and closure of the Palaeo-Asian Oceanic system (Coleman 1994; Buslov et al. 2001).

The Lake Zone represents one of the main lithotectonic domains of the CAOB (Badarch et al. 2002;
Kröner et al. 2010). A number of the arc-related magmatic complexes that make up much of the Lake Zone in western and central Mongolia are considered as a result of exclusively oceanic crust subduction (Badarch et al. 2002; Kovalenko et al. 2004; Rudnev et al. 2012). This magmatism recorded the whole Late Proterozoic-Early Palaeozoic history including the formation of oceanic crust, subduction processes and arc-related magmatic activity. Understanding the timing and nature of magmatism is crucial for deciphering the geotectonic evolution of the Lake Zone and adjacent units. However, the accurate geochronological as well as geochemical data from number of magmatic complexes in the western Mongolian part of the CAOB are still missing.

The aim of this paper is to present results of detailed mapping and petrological study, as well as new $\mathrm{U}-\mathrm{Pb}$ zircon ages and whole-rock geochemical data from the 

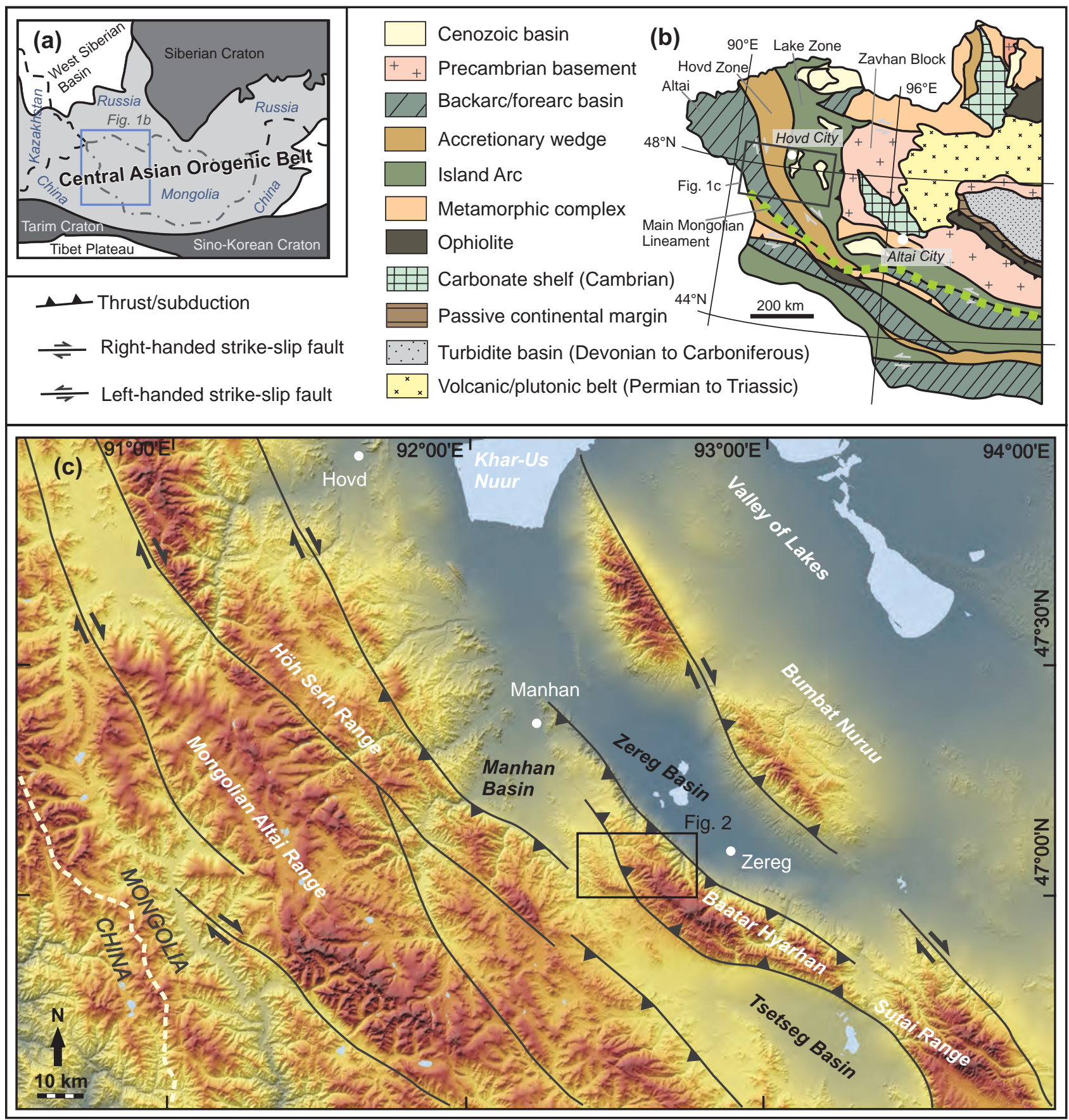

Fig. 1 Maps showing location and geology of the Togtokhinshil Complex. a - Schematic tectonic setting of the Central Asian Orogenic Belt (after Şengör et al. 1993). b - Greatly simplified geological map of the Western Mongolia (after Badarch et al. 2002). c - Location of the Togtokhinshil Complex in Mongolian Altai Mountain Range showing topography, geographical names and major faults, the latter modified from Nissen et al. (2009).

Togtokhinshil Complex in the western Mongolia. Our results constrain the ages, magma sources and petrogenesis of two contrasting magmatic suites, Mid-Ordovician gabbro-dioritic and Late Devonian granitic. The critical comparison with the existing information provides a fresh insight into the mechanism of the Lake Zone formation and, in particular, its accretionary history.

\section{Geological setting}

\subsection{General overview}

The CAOB is located between the Siberian Craton in the north, the Tarim Craton in the southwest and the Sino-Korean Craton in the south (Fig. 1a) and is built by 
tectonic collage of continental segments, magmatic-arc assemblages, ophiolites, back-arc basins and accretionary wedges. The Mongolian part of the CAOB is subdivided into two principal domains according to the main periods of continental growth and accretion (Zonenshain 1973; Badarch et al. 2002; Kröner et al. 2007) that are separated by an important crustal-scale boundary, the Main Mongolian Lineament (Tomurtogoo 1997; Fig. 1b). The northern domain (Caledonian) contains Late Proterozoic ophiolites, Precambrian to Early Palaeozoic metamorphic rocks, and Early Palaeozoic arc-related complexes. The southern domain (Hercynian) is composed of Early to Late Palaeozoic arc-related intrusive and volcanoclastic rocks and contains slivers of ultrabasic rocks and ophiolites (Badarch et al. 2002; Windley et al. 2007).

The lithotectonic subdivision of the CAOB proposed by Badarch et al. (2002) and used in this paper is based on the lithological, structural and geochronological characteristics and mentioned units are separated by strike-slip faults or by suture zones. These geological units, also called "terranes" (Buslov et al. 2001; Badarch et al. 2002, Windley et al. 2007), form NNWSSE elongated belts in the western Mongolia and their lithostratigraphic architecture generally shows a westward younging trend.

The western Mongolian tract of the CAOB (Fig. 1b) is located north of the Main Mongolian Lineament and is built from the east to the west (present-day coordinates are used through this paper) by the following units.

The Zavhan Block is mainly composed of low- and high-grade metamorphic rocks and is interpreted as a segment of the Precambrian Tuva-Mongolian microcontinent (Buslov et al. 2001; Badarch et al. 2002; Windley et al. 2007) displaying the Siberian (Kravchinsky et al. 2001) or the Tarim Craton affinity (Rojas-Agramonte et al. 2011).

The Lake Zone is composed by Cambrian arc-related rocks, which contain relicts of Late Proterozoic ophiolites, Early Palaeozoic eclogites and peridotites (Zonenshain and Kuzmin 1978; Badarch et al. 2002; Buchan et al. 2002; Yarmolyuk et al. 2011, Rudnev et al. 2012, 2013; Jian et al. 2014) associated with formation and closure of the Palaeo-Asian Ocean. This wide tectonic zone is interpreted as an arc-system which was generated from the Late Proterozoic oceanic crust and evolved during the Early Palaeozoic (Badarch et al. 2002; Xiao et al. 2004). The rocks of the Lake Zone are thrusted over the Precambrian basement of the Zavhan Block. Recently Janoušek et al. (2014) and Guy et al. (2015) proposed that the south-western outer margin of the Lake Zone is bordered by a Cambrian magmatic-arc funded on a juvenile metabasic crust.

The Hovd Zone predominantly contains deformed greenschist- to amphibolite-facies metavolcanic and metasedimentary rocks and Lower Palaeozoic flysch sequences. Based on the rock association, the Hovd Zone has been interpreted as an Cambrian-Silurian accretionary wedge (Badarch et al. 2002; Xiao et al. 2004).

The Altai Zone is dominated by Cambrian-Ordovician low-grade, strongly deformed sequence of sedimentary, volcanosedimentary and volcanic rocks and Early Palaeozoic ophiolites (Xiao et al. 2004, 2008). This complex is overlain by Silurian-Early Carboniferous sedimentary and volcanic rocks and was intruded by Devonian-Permian granitic plutons (Wang T et al. 2006; Kozakov et al. 2007). The Altai Zone has been interpreted as a rock assemblage originally developed in back-arc or fore-arc environment (Badarch et al. 2002).

Existing geotectonic models have suggested that these domains were progressively amalgamated by the continuous Early Palaeozoic accretion (Badarch et al. 2002; Xiao et al. 2004; Windley et al. 2007).

\subsection{Geology of the Togtokhinshil Complex area}

The Togtokhinshil Complex area is located at a western margin of the Lake Zone (Fig. 1b), and geographically belongs to the northern part of the Baatar Hairkhan Mountain Range (also referred as Baataryn Nuruu or Baatar Hyarkhan) (Fig. 1c). The Togtokhinshil Complex forms a NW-SE trending belt bordered by subparallel active thrust faults in the SW and NE (Nissen et al. 2009) and crops out between the Cenozoic Zereg Basin in the NE and the Manhan and Tsetseg basins and Carboniferous sediments of the Khurengol Fm. in the SW. The Cenozoic deposits of the Tsetseg Basin partly obscure the contact of the Togtokhinshil Complex with greenschist- to amphibolite-facies metamorphic rocks and the Lower Palaeozoic flysch sequences of the Hovd Zone in the SW (Figs 1c, 2).

The Togtokhinshil Intrusive Complex is made up mainly by diorites, gabbros and granites, which intruded into the Baatar Fm. (low-grade volcanosedimentary sequence). The Mid-Late Cambrian age for the entire Togtokhinshil Complex as well as the Baatar Fm. has been only assumed (Baatarhuyag and Gansukh 1999).

\section{Results}

\subsection{Field observations}

The plutonic rocks of the Togtokhinshil Complex form highly irregular intrusive bodies. In the study area in the central part of the Complex W of the Zereg soum (Hovd aimag) (Fig. 1c), two domains (eastern and western) of 


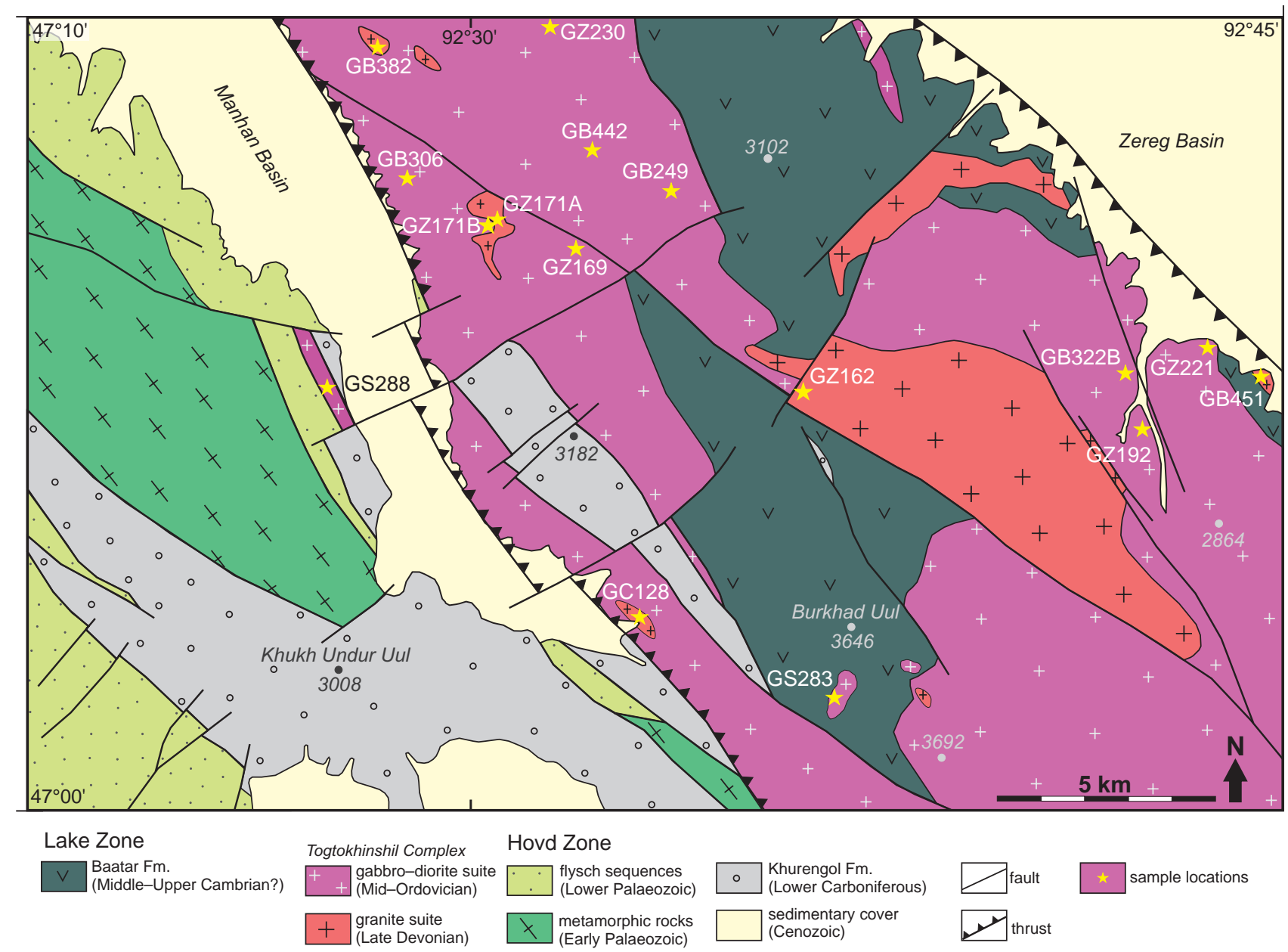

Fig. 2 Simplified geological map of the central part of the Togtokhinshil Complex and the adjacent units (our new mapping). The location of the map is shown as a black rectangle on Fig. 1c. Stars indicate location of geochemical and geochronological samples.

igneous rocks are separated by a zone of the Baatar Fm. roof pendants (Fig. 2).

Based on the field relations, petrology and composition, the wide spectrum of magmatic rock types in the Togtokhinshil Complex can be grouped into (1) gabbrodiorite suite and (2) granite suite.

Magmatic rocks of both suites intruded into the Baatar Fm., which is dominated by low-grade (sub-greenschist to greenschist) basic and acid tuffs, volcanic rocks and subordinated sandstones and greywackes. The contacts between the Baatar Fm. and the magmatic rocks of both suites are sharp, curviplanar and largely discordant to structures in the country rocks. Extensive, 300-1500 $\mathrm{m}$ wide thermal aureole is developed along intrusive contacts.

The gabbro-diorite suite is represented by heterogeneous assemblage of medium- to coarse-grained gabbros and diorites in the western domain and relatively homogeneous medium-grained diorite in the eastern domain. The contacts between gabbros and diorites are complex, felsic gabbrodiorite and diorite commonly enclose angular to subangular blocks of the fine-grained gabbro. Contact of the gabbros and diorites is locally characterized by mixing/mingling textures (light diorite to gabbrodiorite and dark gabbros are intimately comingled - Fig. 3a). Gabbro and diorite enclose numerous fine-grained mafic enclaves of variable size and shape, commonly with complex internal structures and both sharp and diffuse margins (Fig. 3b). The gabbro bodies are typically homogeneous; however, in places they display small-scale internal layering $(0.1-8 \mathrm{~cm})$. Individual layers differ in grain size and proportion between amphibole and plagioclase (Fig. 3c).

The eastern domain of the Togtokhinshil Complex is intruded by two large, and numerous small, bodies of porphyritic medium-grained biotite granite, which crosscut both rocks of the gabbro-diorite suite and the Baatar Fm.

Magmatic rocks of the Togtokhinshil Complex as well as the Baatar Fm. have been designated as MidLate Cambrian in geological map (Baatarhuyag and Gansukh 1999). However, the different relative ages of 

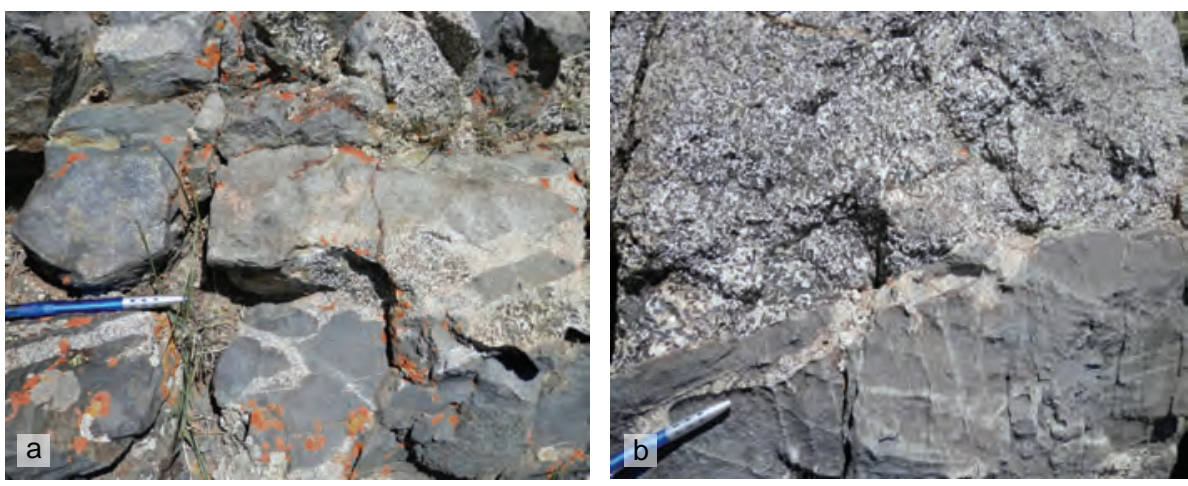

Fig. 3 Field photographs of main magmatic rock types of the Togtokhinshil Complex. a - Mostly round enclaves of amphibole microgabbro within diorite. b - Sharp contact between medium-grained amphibole gabbrodiorite and fine-grained gabbro with chilled margin. c - Internal layering in amphibole gabbro cumulate crosscut by pegmatite veins. d - Ductile shear zone that affected amphibole-biotite gabbro and diorite mixing domain.
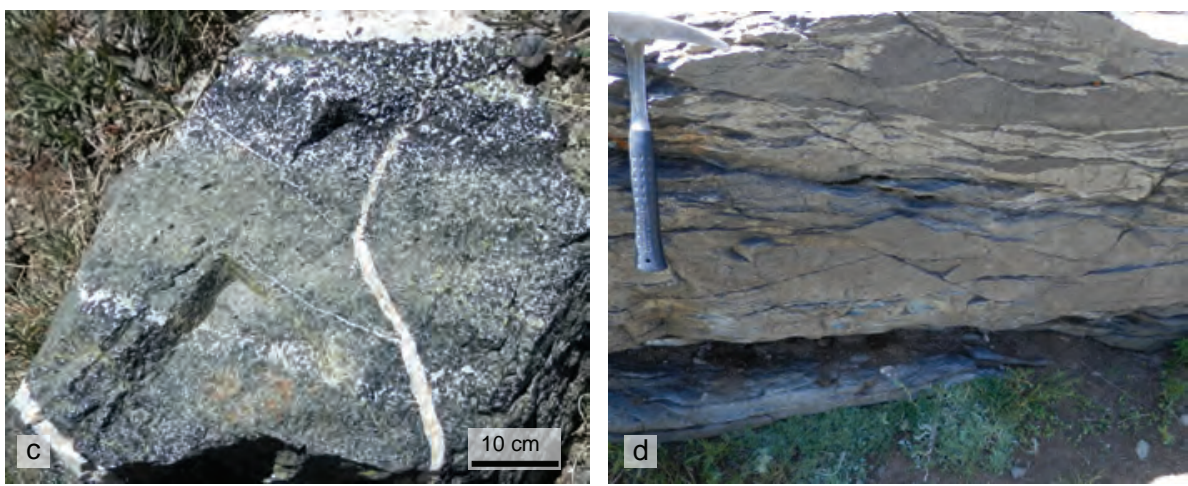

both suites are clearly documented by numerous field observations. Heterogeneously developed NW-SE to NNW-SSE trending magmatic fabric in the rocks of the gabbro-diorite suite is defined by the preferred orientation of amphibole and plagioclase. The rocks of the gabbro-diorite suite have been affected by subsolidus deformation and locally deformed in several hundred meters wide, predominantly $\sim \mathrm{NE}-\mathrm{SW}$ trending, ductile shear zones (Fig. 3d). Porphyritic biotite granite (granite suite) also commonly shows $\sim \mathrm{NW}-\mathrm{SE}$ trending steep magmatic fabric roughly parallel with the margins of granite bodies (Fig. 4a). Granites have been affected by heterogeneous solid-state deformation and lo-

Fig. 4 Textures of main rock types of the Togtokhinshil Complex. a - Weak magmatic fabric in the porphyritic granite defined by the preferred orientation of $\mathrm{K}$-feldspar phenocrysts and mafic microgranular enclaves. $\mathbf{b}$ Photomicrograph of amphibole gabbro with subhedral texture (plane-polarized light). c - Gabbrodiorite with poikilitic phenocrysts of amphibole. d - Photomicrograph of amphibole gabbrodiorite with poikilitic texture (plane-polarized light).
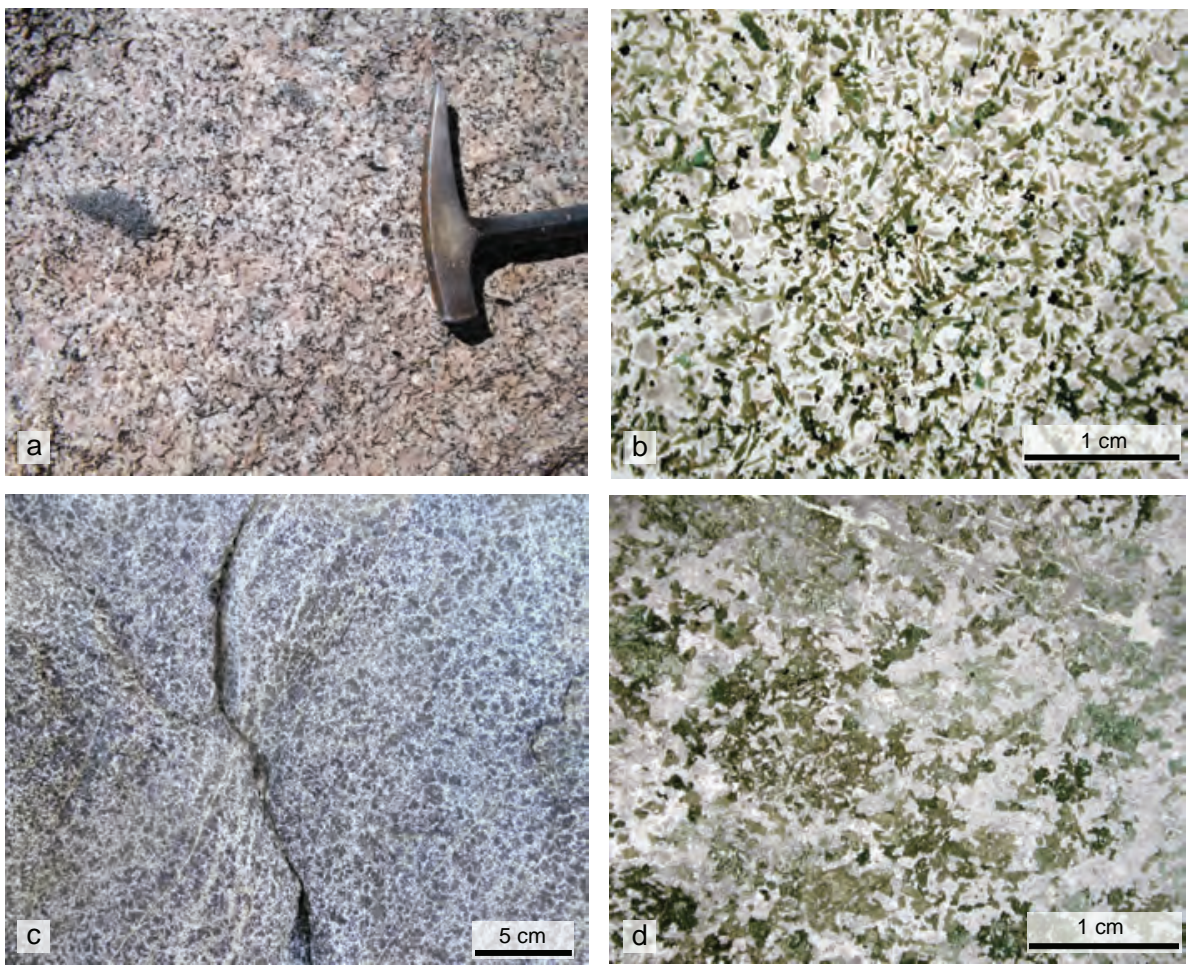

cally display weak foliation sub-parallel to the penetrative magmatic fabric.

The contacts of the Baatar Fm. and both magmatic suites are commonly tectonically reworked. Relicts of the thermally affected host-rocks were also found as numerous septa within gabbros and diorites. Sedimen- 
Tab. 1 Location and brief petrological description of geochemical and geochronological samples from the Togtokhinshil Complex

\begin{tabular}{lccl}
\hline Sample (rock type) & Latitude $(\mathrm{N})$ & Longitude $(\mathrm{E})$ & \\
\hline gabbro-diorite suite & & & \\
GB249 (Gabbro) & 47.129161 & 92.558398 & Pl, Amp, Cpx, (Opx, Ap, Opq) \\
GB306 (Gabbrodiorite) & 47.126673 & 92.483136 & Pl, Amp, (Opq, Ap), Ep \\
GB322B (Gabbrodiorite) & 47.092161 & 92.702063 & Pl, Amp, Bt, Kfs, (Ttn, Opq, Ap), Chl \\
GB442 (Gabbrodiorite) & 47.135873 & 92.541651 & Pl, Amp, Bt, (Opq), Chl \\
GS283 (Gabbro) & 47.022187 & 92.612800 & Amp, Pl, Cpx, (Ap, Opq) \\
GS288 (Microgabbro) & 47.088760 & 92.456825 & Pl, Cpx, Ol, Qtz, (Mag, Ap), Chl, Pmp \\
GZ169 (Gabbro) & 47.117398 & 92.540494 & Pl, Cpx, Amp, (Ap, Opq), Chl \\
GZ171B (Gabbrodiorite) & 47.119711 & 92.507164 & Pl, Amp, Bt, (Qtz, Ap, Opq), Ep, Prh \\
GZ192 (Gabbro) & 47.081407 & 92.706744 & Pl, Amp, Kfs, (Ap, Zrn), Ep, Ms, Ccp, Lm \\
GZ221 (Gabbro) & 47.096286 & 92.729710 & Pl, Amp, Cpx, Kfs, Ol (Opq, Ap) \\
GZ230 (Gabbrodiorite) & 47.167112 & 92.523391 & Amp, Pl, Czo, (Opq, Ttn), Ep, Chl \\
\hline granite suite & & \\
GB382 (Porphyritic granite) & 47.162175 & 92.468410 & Kfs, Pl, Qtz, Bt, (Opq, Ap), Chl \\
GB451 (Porphyritic granite) & 47.091094 & 92.743591 & Kfs, Pl, Qtz, Bt, (Opq, Zrn, Ap), Chl \\
GC128 (Equigranular granite) & 47.039096 & 92.553560 & Pl, Kfs, Qtz, Bt, (Opq), Ep \\
GZ162 (Porphyritic granite) & 47.088021 & 92.598242 & Kfs, Pl, Qtz, Bt, (Ap, Ttn, Opq, Mag) \\
GZ171A (Equigranular granite) & 47.119711 & 92.507164 & Pl, Kfs, Qtz, Bt, (Ap, Czo, Zrn, Mag, Ttn), Chl \\
\hline
\end{tabular}

tary bedding in the meta-volcanosedimentary rocks of the Baatar Fm. is folded to symmetric, tight to isoclinal upward folds, associated with a locally developed steep $\sim \mathrm{NW}-\mathrm{SE}$ striking cleavage and dextral top-tothe-SW and NE shearing. Thus, their axial planes are roughly parallel to the regional magmatic fabric that is widespread in the bodies of the porphyritic biotite granite.

All the magmatic rocks of the Togtokhinshil Complex as well as their host-rocks are penetrated by numerous dykes and veins of diorites, dolerites, granites, aplites and pegmatites (Fig. 3c). Granite, pegmatite and aplite dykes (up to $40 \mathrm{~cm}$ thick) predominantly occur in the vicinity of granite bodies. They are generally steep and strike $\sim \mathrm{W}-\mathrm{E}$ or $\sim \mathrm{NW}-\mathrm{SE}$, exceptionally $\sim \mathrm{NE}-\mathrm{SW}$.

\subsection{Petrography and mineral chemistry of the Togtokhinshil Complex rocks}

\subsubsection{Gabbro-diorite suite}

Diorites and gabbros dominate in the Togtokhinshil Complex and occur in several subtypes according to their texture and grain-size (Figs 3-4); the contact between gabbros and diorites is frequently diffuse. The gabbros show medium- to coarse-grained subhedral ophitic tex-

Tab. 2 Composition of amphiboles, estimated P-T conditions, oxygen fugacity and water content for magmas of the gabbro-diorite suite

\begin{tabular}{|c|c|c|c|c|c|}
\hline $\begin{array}{l}\text { Rock } \\
\text { Sample }\end{array}$ & $\begin{array}{c}\text { Gabbro } \\
\text { Opx-Amp } \\
\text { GB249 }\end{array}$ & $\begin{array}{c}\text { Gabbro } \\
\text { Cpx-Amp } \\
\text { GZ221 }\end{array}$ & $\begin{array}{c}\text { Gabbro } \\
\text { Cpx-Amp } \\
\text { GS283 }\end{array}$ & $\begin{array}{c}\text { Gabbrodiorite } \\
\text { Bt-Amp } \\
\text { GZ192 }\end{array}$ & $\begin{array}{c}\text { Gabbrodiorite } \\
\text { Bt-Amp } \\
\text { GB171B }\end{array}$ \\
\hline Plagioclase (An mol. \%) & $50-61$ & $55-84$ & $68-90$ & $35-58$ & $40-41$ \\
\hline Amphibole $\left(\mathrm{X}_{\mathrm{Mg}}\right)$ & $0.67-0.77$ & $0.43-0.94$ & $0.63-0.77$ & $0.56-0.60$ & $0.80-0.82$ \\
\hline Amphibole (Si) & $6.30-8.27$ & $6.04-7.40$ & $5.97-7.72$ & $6.67-6.72$ & $6.76-6.79$ \\
\hline \multicolumn{6}{|c|}{ Amphibole thermobarometry (Ridolfi et al. 2010)* } \\
\hline $\mathrm{T}\left({ }^{\circ} \mathrm{C}\right)$ & 853 to 948 & 904 to 921 & 930 to 990 & 840 & 821 to 822 \\
\hline Uncertainty ( $\sigma$ est) & 22 & 22 & 22 & 22 & 22 \\
\hline $\mathrm{P}(\mathrm{GPa})$ & 0.17 to 0.34 & 0.25 to 0.28 & 0.33 to 0.65 & 0.16 & 0.14 to 0.15 \\
\hline Uncertainty (Max. error) & 0.02 to 0.04 & 0.03 & 0.04 to 0.12 & 0.02 & 0.02 \\
\hline $\log \mathrm{fO}_{2}$ & -11.8 to -11.0 & -11.4 to -11.2 & -11.3 to -9.8 & -12.6 & -12.0 to -11.9 \\
\hline Uncertainty ( $\sigma$ est) & 0.4 & 0.4 & 0.4 & 0.4 & 0.4 \\
\hline $\mathrm{H}_{2} \mathrm{O}$ melt (wt.\%) & 5.6 to 6.2 & 5.0 to 5.5 & 5.4 to 9.9 & 5.3 & 6.6 \\
\hline Uncertainty & 0.4 to 0.9 & 0.8 & 1.1 to 1.5 & 0.4 & 0.4 \\
\hline \multicolumn{6}{|c|}{ Plagioclase - Hornblende thermometry (Holland and Blundy 1994) } \\
\hline $\mathrm{T}\left({ }^{\circ} \mathrm{C}\right) \pm 32^{\circ} \mathrm{C}$ & 771 to 867 & 853 to 866 & 817 to 901 & 712 to 750 & 741 to 749 \\
\hline \multicolumn{6}{|c|}{ Amphibole barometry (Anderson and Smith 1995)* } \\
\hline $\mathrm{P}(\mathrm{GPa})$ & 0.16 to 0.33 & 0.14 to 0.15 & 0.20 to 0.41 & 0.35 to 0.36 & 0.27 to 0.28 \\
\hline
\end{tabular}

* temperature according to plagioclase-hornblende thermometry (Holland and Blundy 1994) 
tures (Fig. 4b) and consist mainly of plagioclase (25-65 vol. \%), variable amount of amphibole (30-68 vol. $\%$ ), clinopyroxene (up to 40 vol. \%) or orthopyroxene (up to 10 vol. \%) and biotite (up to 5 vol. \%) with rare K-feldspar (up to 3 vol. \%).

Plagioclase is represented mostly by subhedral to euhedral labradorite-bytownite $\left(\mathrm{An}_{50-90}\right)$ with normal or patchy zoning. Amphiboles do not show any significant zoning and their chemical composition corresponds to magnesiohornblende, pargasite, edenite and rarely tschermakite and ferrotschermakite (Leake et al. 2003) with Si $=5.97-7.77$ apfu and, $X_{\mathrm{Mg}}=0.3-0.94$. Clinopyroxene (diopside; $X_{\mathrm{Fe}}=0.27-0.29$ ) in the subhedral crystals $(2-5 \mathrm{~mm})$ is partly replaced by brown and green amphibole. Orthopyroxene is represented by anhedral enstatite (Morimoto et al. 1988) with $X_{\mathrm{Fe}}=0.31-0.34$ and usually occurs as inclusions within the amphibole. Exceptionally, fibrous edenite with abundant magnetite inclusions was found that likely replaced the orthopyroxene. Tremolite-talc pseudomorphs probably after olivine are locally developed. Accessory minerals include zircon, ilmenite, magnetite and apatite. Observed textural features indicate significant effects of crystal fractionation and crystal accumulation in gabbros.

Diorites and gabbrodiorites, which dominate in the eastern domain of the Togtokhinshil Complex, are characterized by fine- to medium-grained subhedral to poikilitic textures (Fig. 4c-d). Medium-grained biotite-amphibole and amphibole diorite are very common, occasionally with porphyritic texture. Groundmass contains subhedral, lath-shaped complexly zoned plagioclase (30-62 vol. \%), biotite (0-30 vol. \%) and amphibole (20-47 vol. \%). Accessory minerals include ilmenite, magnetite, apatite, zircon and scarce chalcopyrite.

Gabbros and medium-grained diorites frequently contain fine-grained mafic enclaves up to $3 \mathrm{~m}$ in diameter. According to basicity of plagioclase, these enclaves can be also classified as gabbro or diorite. Euhedral plagioclase megacrysts (up to $4 \mathrm{~mm}$ ) are locally present. The groundmass is mostly randomly oriented with lath-shaped plagioclase (40-60 vol. \%), intergranular amphibole (15-40 vol. \%), biotite (0-20 vol. \%), occasional orthopyroxene ( $0-25$ vol. \%), and accessory ilmenite and magnetite.

\subsubsection{Granite suite}

The porphyritic medium-grained biotite granite is composed of perthitic K-feldspar phenocrysts 3-8 $\mathrm{mm}$ long (24-38 vol. \%), plagioclase (20-30 vol. \%), anhedral quartz (19-25 vol. \%), biotite (10-16 vol. \%) and commonly contains oblate mafic microgranular enclaves (Fig. 4a) and biotite-rich schlieren. K-feldspar phenocrysts are chemically relatively homogeneous $\left(\mathrm{Ab}_{3-7}\right)$ and subhedral to anhedral plagioclase in the groundmass is classified as oligoclase $\left(\mathrm{An}_{15-21}\right)$. Titanite, ilmenite, magnetite, apatite, zircon, and allanite are typical primary accessories.

Smaller bodies of porphyritic biotite granite, as well as equigranular biotite granite related to the main granite body, occur also elsewhere in the Togtokhinshil Complex (Fig. 2). Equigranular medium-grained granite contains subhedral to euhedral K-feldspar (18-30 vol. \%), mostly subhedral plagioclase (25-40 vol. \%) and anhedral quartz (20-32 vol. \%). Biotite and/or amphibole account for up to $5-15$ vol. $\%$. The accessory minerals are titanite, magnetite, apatite and zircon.

\subsection{Crystallization conditions of the gabbro- diorite suite}

The mineral assemblages in the gabbros and gabbrodiorites permit determination of $\mathrm{P}-\mathrm{T}$ conditions of crystallization by means of the calcic amphibole thermobarometry (Ridolfi et al. 2010). Analytical methods and representative electron microprobe analyses are given in supplementary materials 1 and 2 . All studied rocks contain magmatic amphiboles (Fig 5; Tab. 2) with relatively constant $\mathrm{Ti}$ and Na contents of $0.10-0.38$ and $0.10-0.38$ apfu, respectively.

The estimated crystallization temperatures of amphiboles from gabbros are $853-948^{\circ} \mathrm{C}$ and pressures 0.17-0.34 GPa (Fig. 6a; Tab. 2), except sample GS283. Central parts of amphibole crystals from this sample, which have pargasite composition, yielded higher $\mathrm{P}-\mathrm{T}$ conditions $\left(930-990^{\circ} \mathrm{C}\right.$ and $\left.0.33-0.65 \mathrm{GPa}\right)$. For the gabbrodiorites, $\mathrm{P}-\mathrm{T}$ conditions in the range of $821-840^{\circ} \mathrm{C}$ and $0.14-0.16 \mathrm{GPa}$ were obtained.

The amphibole barometry of Anderson and Smith (1995) and edenite-richterite thermometer (Holland and Blundy 1994) have been applied for the independent test of the $\mathrm{P}-\mathrm{T}$ conditions estimated by the method of Ridolfi et al. (2010). The plagioclase inclusions in the amphibole or rim compositions of small plagioclase grains, which could be contemporaneous with the amphibole crystallization, were used for calculation. Nevertheless, slightly lower pressures and temperatures for gabbros and somewhat higher pressures and lower temperatures for gabbrodiorites were obtained in comparison to Ridolfi et al. (2010) formulation (Tab. 2 ). Differences probably resulted from the subsolidus reequilibration. The amphiboles in most of samples of the gabbro-diorite suite equilibrated at the depth of $c$. $5-13 \mathrm{~km}$ (for average density $2.7 \mathrm{~g} / \mathrm{cm}^{3}$ of the continental crust).

The Ridolfi et al. (2010) formulation also provides an estimate of oxygen fugacity during amphibole crystallization (Fig. 6b; Tab. 2). Similar values were obtained for all studied gabbro $\left(\mathrm{fO}_{2}-9.8\right.$ to -11.8$)$ and gabbrodiorite $\left(\mathrm{fO}_{2}\right.$ 

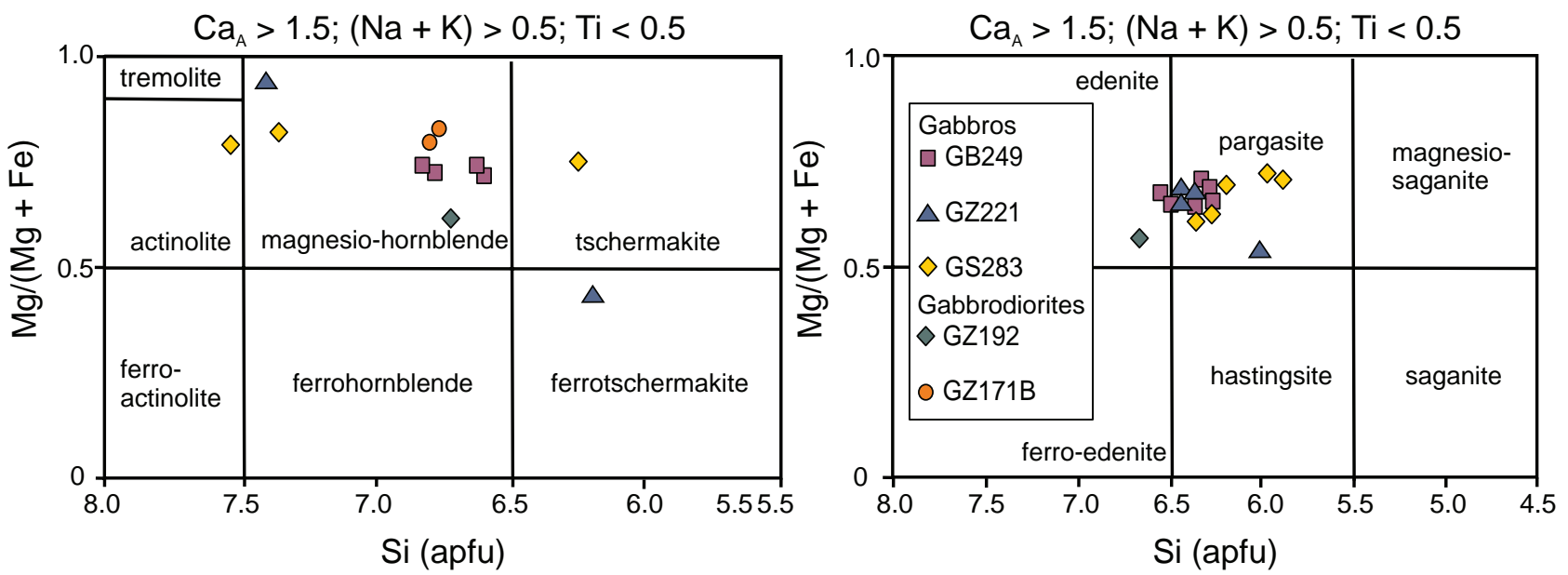

Fig. $5 \mathrm{Si}$ vs. $\mathrm{Mg} /(\mathrm{Mg}+\mathrm{Fe})(\mathrm{apfu})$ classification plot of calcic amphiboles (Leake et al. 2003).

-11.9 to -12.6$)$ samples. The estimated water contents in the melt calculated using the amphibole composi-

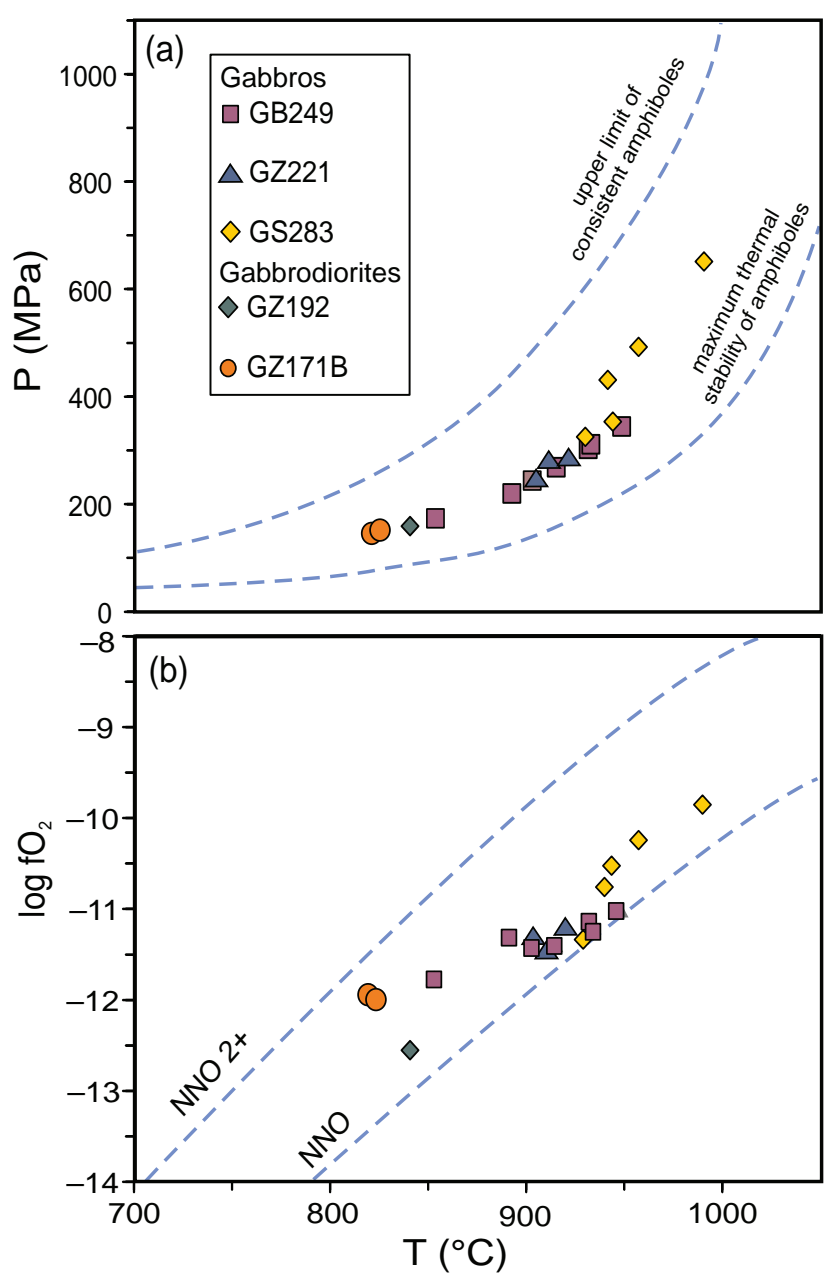

Fig. 6 Crystallization conditions for the rocks of the gabbro-diorite suite recorded in calcic amphibole calculated after Ridolfi et al. (2010). $\mathbf{a}-\mathrm{T}$ vs. $\mathrm{P}$ diagram. $\mathbf{b}-\mathrm{T}$ vs. oxygen fugacity with curves of the nickel-nickel oxide (NNO) buffers. tion (Ridolfi et al. 2010; Tab. 2) are similar for gabbro (5.0-9.9 wt. \%) and gabbrodiorite (5.3-6.6 wt. \%).

\subsection{Whole-rock geochemistry}

The rocks of the Togtokhinshil Complex are characterized by 16 newly obtained whole-rock analyses (Fig. 2; Tab. 1). Based on petrography, they are divided into two groups: gabbro-diorite suite (gabbro, gabbrodiorite and diorite) and granite suite (granites) (Fig. 7a; Cox et al. 1979). The rocks of the gabbro-diorite suite are represented by five gabbros, one microgabbro and five gabbrodiorites. To the granite suite belong three porphyritic medium-grained biotite granite and two equigranular biotite granite samples. Analytical methods for the wholerock geochemistry are described in Supplementary material 1. Major- and trace-element whole-rock geochemical analyses are listed in supplementary materials 3 and 4 .

\subsubsection{Major elements}

Major-element composition of the gabbro-diorite suite is basic to intermediate $\left(\mathrm{SiO}_{2}=43.3-53.2\right.$ wt. \%; Fig. 7a) with highly variable $\mathrm{K}_{2} \mathrm{O}$ contents and $\mathrm{K}_{2} \mathrm{O} / \mathrm{Na}_{2} \mathrm{O}$ ratios (0.04-0.7). The rocks of the granite suite are silicic $\left(\mathrm{SiO}_{2}=67.1-76.3\right.$ wt. \%) and have relatively low $\mathrm{K}_{2} \mathrm{O} / \mathrm{Na}_{2} \mathrm{O}$ ratios $(0.5-1.7$ by weight). Based on the multi-element B-A diagram (Debon and Le Fort 1983), the rocks of the gabbro-diorite suite are moderately metaluminous whereas the granites are subaluminous (Fig. 7b). In the AFM (Irvine and Baragar 1971; Fig. 7c) and $\mathrm{Al}-\mathrm{Fe}^{\mathrm{T}}+\mathrm{Ti}-\mathrm{Mg}$ (Jensen 1976; Fig. 7d) triangular plots, the granites show a calc-alkaline character. The situation with gabbros and gabbrodiorites is not so clear, in part because many of the gabbros represent cumulates; still it cannot be excluded that some of them are tholeiitic. 
Based on the $\mathrm{SiO}_{2}-\mathrm{K}_{2} \mathrm{O}$ plot of Peccerillo and Taylor (1976) (Fig. 7e) and especially its alternative using the less mobile elements Co and Th (Hastie et al. 2007) (Fig. 7f), the gabbro-diorite suite shows low to normal calc-alkaline character, while the granite suite is classified as mainly high-K calc-alkaline to shoshonitic.

\subsubsection{Trace elements}

The trace-element contents of all the rocks from the Togtokhinshil Complex were normalized by normal mid-ocean ridge basalt (N-MORB; Sun and McDonough 1989) and plotted as spider diagrams in which only the presumably little mobile elements are shown (Pearce 2014; Fig. 8a, c). Moreover, the chondrite-normalized (Boynton 1984) REE (Rare Earth Elements) patterns are also provided (Fig. 8b, d). All spider plots are colour-coded according to the silica contents in individual samples.

Compared with average NMORB, the multielement patterns of the gabbro-diorite suite (Fig. 8a) are characterized by enrichment in Th, and often also in LREE (Light REE). On the other hand, the normalized contents of $\mathrm{Zr}$, Hf, MREE (Middle REE) and, in particular, of HREE (Heavy REE) are mostly below unity. Characteristic of all patterns are deep troughs in $\mathrm{Nb}$ and $\mathrm{Ta}$, and most of them negative anomalies of Ti, albeit less noticeable ones. In general, there is an increase in contents of more

Fig. 7 Classification diagrams for plutonic rocks of the Togtokhinshil Complex. a - TAS diagram (Cox et al. 1979). b Multi-element B-A diagram (Debon and Le Fort 1983). B represents the content of mafic minerals and A the balance of aluminium vs. alkalis. Mineral assemblages typical of each of the sectors are also marked. c - AFM ternary diagram (Irvine and Baragar 1971). d - Triangular plot Al-Fe ${ }^{\mathrm{T}}+\mathrm{Ti}-\mathrm{Mg}$ (Jensen 1976). CA: calc-alkaline, TH: tholeiitic, 1 : high-Mg tholeiitic basalt. e - $\mathrm{SiO}_{2}$ vs. $\mathrm{K}_{2} \mathrm{O}$ diagram (Peccerillo and Taylor 1976). f - Co vs. Th plot (Hastie et al. 2007). B: basalt, BA/A: basaltic andesite and andesite, $\mathrm{D} / \mathrm{R}^{*}$ : dacite and rhyolite. incompatible elements, especially of Th and LREE, with rising whole-rock $\mathrm{SiO}_{2}$ (i.e. going from gabbros to gabbrodiorites).

The rocks of the gabbro-diorite suite show two different types of REE patterns (Fig. 8b). Gabbros are characterized by relatively low total REE contents (14-118 ppm) and display flat chondrite-normalized REE patterns $\left(\mathrm{La}_{\mathrm{N}} / \mathrm{Yb}_{\mathrm{N}}=0.6-8.9\right)$ with slightly positive to no $\mathrm{Eu}$ anomalies $\left(\mathrm{Eu} / \mathrm{Eu}^{*}=0.9-1.4\right)$. Still, some REE patterns for gabbros are distinctly influenced by crystal accumulation, as was already noted in the field and during petrological study. The most instructive are the cases of samples GS283 (an Amp-Pl cumulate with
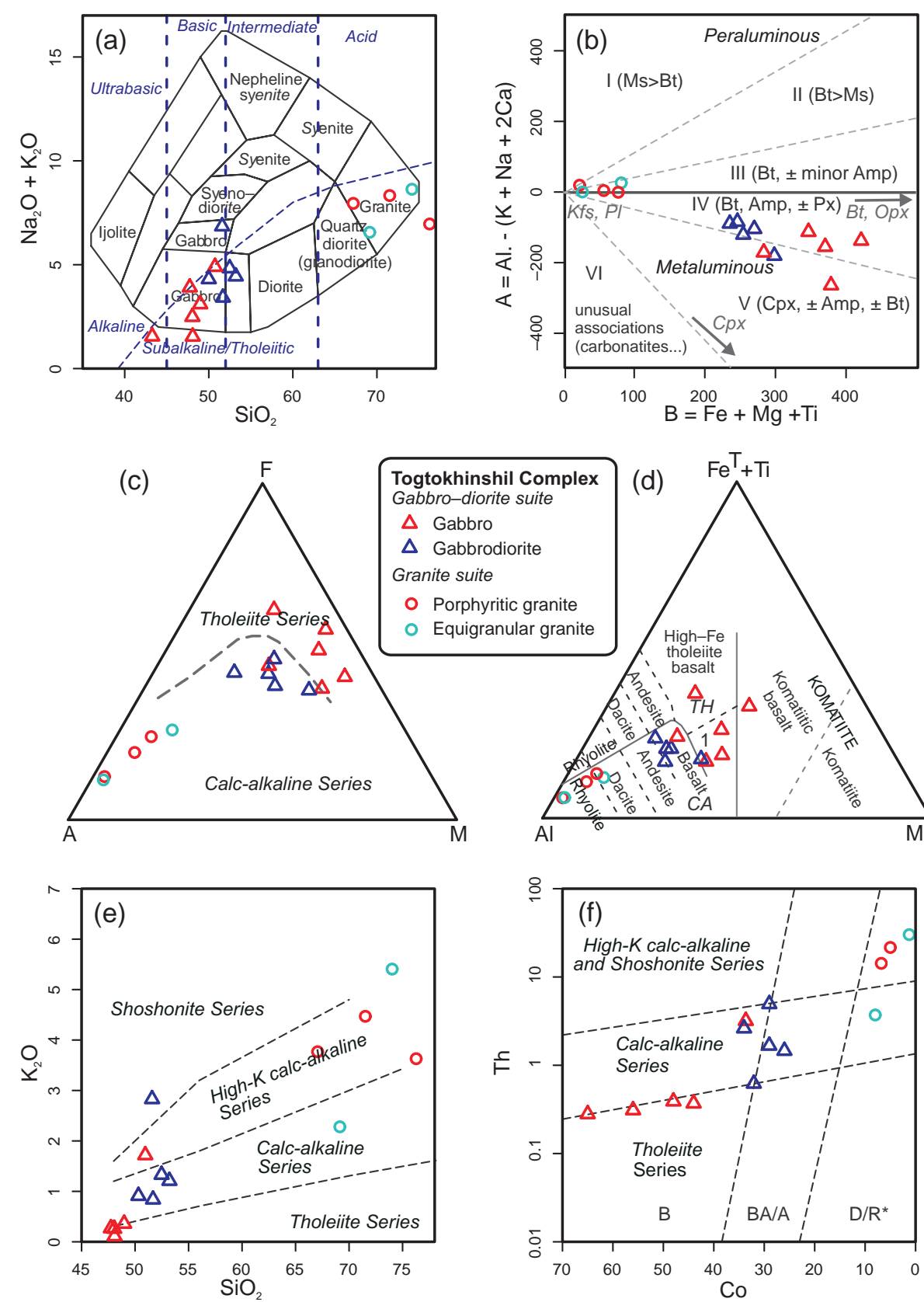

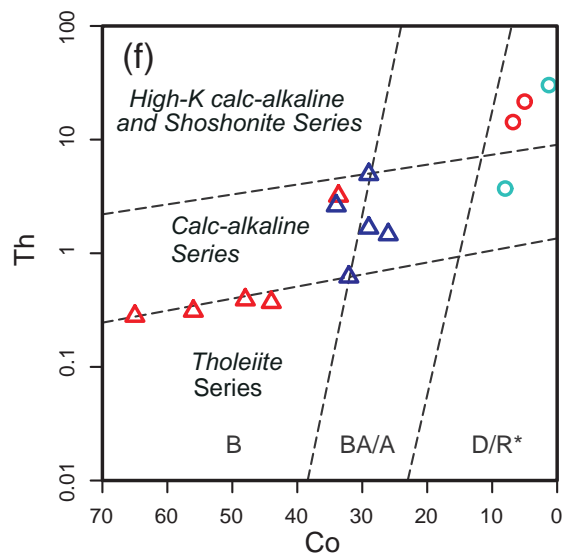


convex pattern and slight positive Eu anomaly), GZ169 (enriched in $\mathrm{Pl}$ as shown by low HREE and significant positive Eu anomaly) and GS288 (a Di-rich rock with elevated HREE contents). On the other hand, the gabbrodiorites are richer in REE (60-220 ppm), especially in the LREE. Their chondrite-normalized REE patterns are steeper $\left(\mathrm{La}_{\mathrm{N}} / \mathrm{Yb}_{\mathrm{N}}=3.9-18.1\right)$ without significant $\mathrm{Eu}$ anomalies $\left(\mathrm{Eu} / \mathrm{Eu}^{*}=0.9-1.1\right)$.

The multielement patterns for the granite suite are characterized by strong enrichment in Th and LREE compared with NMORB (Fig. 8c). The HREE are always lower, and $\mathrm{Zr}$ with $\mathrm{Hf}$ variable, from slightly enriched to close to unity. Compared with adjacent elements, negative $\mathrm{Nb}$, Ta and $\mathrm{Ti}$ anomalies are conspicuous in all the samples. Overall, the patterns fall between the upper and lower continental crust averages after Taylor and McLennan (1995). i.e. within the grey shaded area in Fig. 8c.

Rocks of the granite suite have relatively low REE concentrations ranging from 96 to $172 \mathrm{ppm}$. Chondrite-normalized REE patterns (Fig. 8d) show a strong LREE enrichment $\left(\mathrm{La}_{\mathrm{N}} / \mathrm{Sm}_{\mathrm{N}}=4.8-10.5\right)$, variable degree of fractionation of the $\operatorname{HREE}\left(\mathrm{La}_{\mathrm{N}} / \mathrm{Yb}_{\mathrm{N}}=\right.$ 8.8-47.5) and variably developed Eu anomalies (Eu/ $\left.\mathrm{Eu}^{*}=0.5-1.1\right)$.
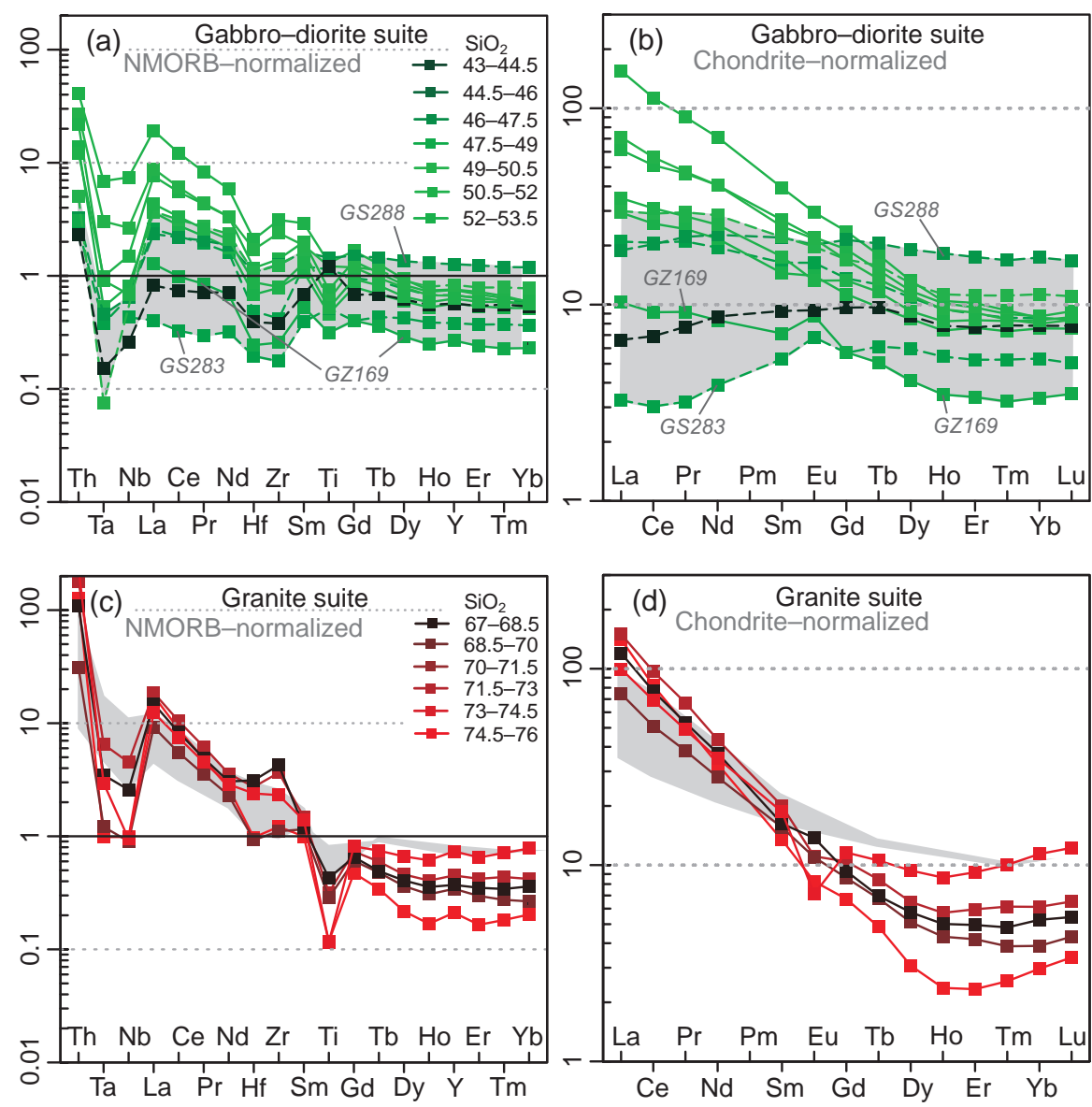

\subsection{Nd isotope geochemistry}

The Nd isotope compositions of two dated samples, both raw and age-corrected, are given in the Tab. 3. Analytical methods for the $\mathrm{Nd}$ isotope geochemistry are described in Buriánek et al. (this volume). The Nd isotopic composition of gabbrodiorite GZ171B (gabbro-diorite suite) is fairly primitive, having $\varepsilon_{N d}^{460}=+6.5$, corresponding to a low single-stage $\mathrm{Nd}$ model age $\left(T_{D M}^{N d}=0.72 \mathrm{Ga}\right)$. The granite GZ162 (granite suite) contains relatively less radiogenic $\mathrm{Nd}\left(\varepsilon_{N d}^{376}=+3.8\right)$ and has a little higher twostage $\mathrm{Nd}$ model age $\left(T_{D M}^{N d}=0.78 \mathrm{Ga}\right)$. Taken together, the $\mathrm{Nd}$ isotopic signatures show that the magmas of the both magmatic suites from the Togtokhinshil Complex were likely derived from relatively young, and geochemically immature, sources.

\subsection{U-Pb zircon geochronology}

Two samples from the most significant rock types of the Togtokhinshil Complex, biotite-amphibole gabbrodiorite of the gabbro-diorite suite (GZ171B) and porphyritic biotite granite of the granite suite (GZ162), were dated using LA-ICP-MS zircon U-Pb analysis. Analytical details are shown in Supplementary material 1; U-Pb isotopic data and corresponding ages in Supplementary material 5 .

The zircon grains from gabbrodiorite GZ171B are predominantly clear, light pink to pale brown and generally have longprismatic shapes with a length of $200-600 \mu \mathrm{m}$. In cathodoluminescence images (Fig. 9), most of the zircon grains have euhedral, unzoned cores sometimes retaining ghost domains. These domains are probably

Fig. 8 Multielement diagrams colour-coded by silica contents. a - NMORB-normalized (Sun and McDonough 1989) trace-element patterns for the gabbro-diorite suite. b - Chondrite-normalized (Boynton 1984) REE patterns for the gabbro-diorite suite. In both figures, the grey shaded area represents the compositional range of the gabbros. c - NMORB-normalized (Sun and McDonough 1989) trace-element patterns for the granite suite. $\mathbf{d}$ - Chondrite-normalized (Boynton 1984) REE patterns for the granite suite. The grey shaded area in figures $\mathrm{c}-\mathrm{d}$ represents the range of chemical compositions between the average upper and lower continental crust (Taylor and McLennan 1995). 
related to local recrystallization of radiation-damaged parts of the crystals. Some grains show a thin concentric oscillatory-zoned pattern in the rims that are attributed to the crystallization from the melt (Fig. 9). Infrequent oscillatory zoning in the zircon cores is mostly parallel to the long $C$-axes. The observed internal zoning pattern is typical of igneous zircons from shallow-level basic to intermediate rocks (e.g., Hoskin 2000). U-Pb zircon dating of sample GZ171B yielded concordant age between c. $455 \mathrm{Ma}$ and $466 \mathrm{Ma}$ (Supplementary material 5). Mean concordia age of $459 \pm 2 \mathrm{Ma}(2 \sigma ; 21$ analyses; Fig. 10a) is interpreted as magmatic formation age of the gabbrodiorite. No inherited zircon core ages were detected.

The studied grains have Th/U ratios (Supplementary material 5) of $0.5-1.7$ (average 0.9 ), i.e. typical of magmatic zircons that are usually $>0.5$ (Rubatto 2002; Hoskin and Schaltegger 2003 and references therein).

Zircon population from the granite GZ162 consists of mainly clear, light brown to colourless and euhedral, prismatic grains with a length of $100-350 \mu \mathrm{m}$. Cathodoluminescence images (Fig. 9) show mostly euhedral oscillatory growth zoning and frequent homogeneous unzoned or faintly zoned cores.

Zircons from sample GZ162 yielded concordant ages of 370 to $385 \mathrm{Ma}$ and weighted mean concordia age of $376 \pm 2 \mathrm{Ma}(2 \sigma, 20$ analyses; Fig. 10) interpreted as timing the granite crystallization. Presence of older zircon ages in the cores was not detected. The high $\mathrm{Th} / \mathrm{U}$ values (0.5-1.1; average 0.7$)$ resemble sample GZ 171B (Supplementary material 5).

\section{Discussion}

\subsection{The age and possible genesis of the rocks forming the Togtokhinshil Complex}

The newly obtained zircon $\mathrm{U}-\mathrm{Pb}$ geochronological data indicate that Togtokhinshil Complex consists of two diachronous rock associations, the Mid-Ordovician gabbro-diorite suite and the Late Devonian granite suite. The contrasting petrology and whole-rock geochemical signature undoubtedly reflects principal differences in sources, petrogenetic processes and geodynamic setting of the two suites. The tectonic environment is dicussed mainly on the basis of the geotectonic diagrams (Fig. 11).

\subsubsection{Gabbro-diorite suite}

In multi-element $\mathrm{R}_{1}-\mathrm{R}_{2}$ plot (Batchelor and Bowden 1985; Fig. 11a), most of the samples of the gabbrodiorite suite fall into the Pre-plate collision (subduction) field, even though some analyses are shifted owing to effects of accumulation (e.g., GS283 of Amp + Pl, GB322B of Amp + Bt). In the $\mathrm{Th}-\mathrm{Hf} / 3-\mathrm{Nb} / 16$ ternary plot of Wood (1980) (Fig. 11b) the gabbros fall into the IAT (island-arc tholeiites) and the gabbrodiorites into the CAB (calc-alkaline basalts) field. Moreover, the $\mathrm{Nb} /$ $\mathrm{Yb}-\mathrm{Th} / \mathrm{Yb}$ plot of Pearce (2008) confirms the volcanicarc nature of gabbro-diorite suite (Fig. 11c).

The low silica contents, high MgO and mg\# (Supplementary materials 3 and 4) as well as the exclusively metaluminous chemistry require an origin of the magmas parental to the gabbros from the mantle source. However, some of the gabbros show a clear field, petrological and geochemical (especially REE) evidence for crystal accumulation (Amp, Pl and/or Cpx) in course of fractional crystallization. The most siliceous (gabbrodiorites) samples could theoretically represent late products of this fractionation or could have been generated by remelting of pre-existing, geochemically rather juvenile oceanic crust. However, the low $\mathrm{SiO}_{2}$ contents of the gabbrodiorites seem to argue against the latter hypothesis.

The low-K to normal-K calc-alkaline geochemical signature and, in particular, obvious enrichments of LILE and LREE and depletions in the HFSE, point to an origin within a magmatic-arc (e.g., Wilson 1989; Pearce 1982; Pearce and Peate 1995). The lack of felsic magmatic rocks and the volcano-sedimentary character of the host-rocks may provide arguments for their intra-oceanic provenance (island-arc).

As an alternative, the same rock association with the observed whole-rock geochemical fingerprint could have originated during subduction under rather young and geochemically primitive continental margin. In this case the rising mafic melts from Mid-Ordovician subductionmodified mantle wedge would trigger partial melting of juvenile continental crust, built for instance by previously accreted island-arc(s).

The highly positive $\varepsilon_{N d}^{460}$ value and Depleted Mantle $\mathrm{Nd}$ model age of $0.72 \mathrm{Ga}$ for the gabbrodiorite GZ171B corresponds well with the published whole-rock $\mathrm{Nd}$ iso-

Tab. $3 \mathrm{Nd}$ isotopic data for the main magmatic rocks of the Togtokhinshil Complex

\begin{tabular}{llccccccccc}
\hline Sample & \multicolumn{1}{c}{ Suite } & Age & $\begin{array}{c}\mathrm{Sm} \\
(\mathrm{ppm})\end{array}$ & $\begin{array}{c}\mathrm{Nd} \\
(\mathrm{ppm})\end{array}$ & ${ }^{147} \mathrm{Sm} /{ }^{144} \mathrm{Nd}$ & ${ }^{143} \mathrm{Nd} /{ }^{144} \mathrm{Nd}^{1}$ & $2 \mathrm{se}$ & ${ }^{143} \mathrm{Nd}^{/ 144} \mathrm{Nd}_{\mathrm{i}}{ }^{2}$ & $\varepsilon_{N d}^{i}$ & $T_{D M}^{N^{N d}{ }^{3}}$ \\
\hline GZ171B (Gabbrodiorite) & gabbro-diorite suite & 460 & 4.31 & 17.1 & 0.1524 & 0.512836 & $3,3 \mathrm{E}-05$ & 0.512377 & 6.5 & $0.72(1 \mathrm{stg})$ \\
GZ162 (Porphyritic granite) & granite suite & 376 & 3.17 & 22.3 & 0.0859 & 0.512561 & $1,8 \mathrm{E}-05$ & 0.512349 & 3.8 & $0.78(2 \mathrm{stg})$ \\
\hline
\end{tabular}

${ }^{1}$ followed by error ( 2 standard errors of the mean)

${ }^{2}$ subscripts 'i' indicate age-corrected isotopic ratios

${ }^{3}$ Single or two-stage Nd model ages (Ga) (Liew and Hofmann 1988) 


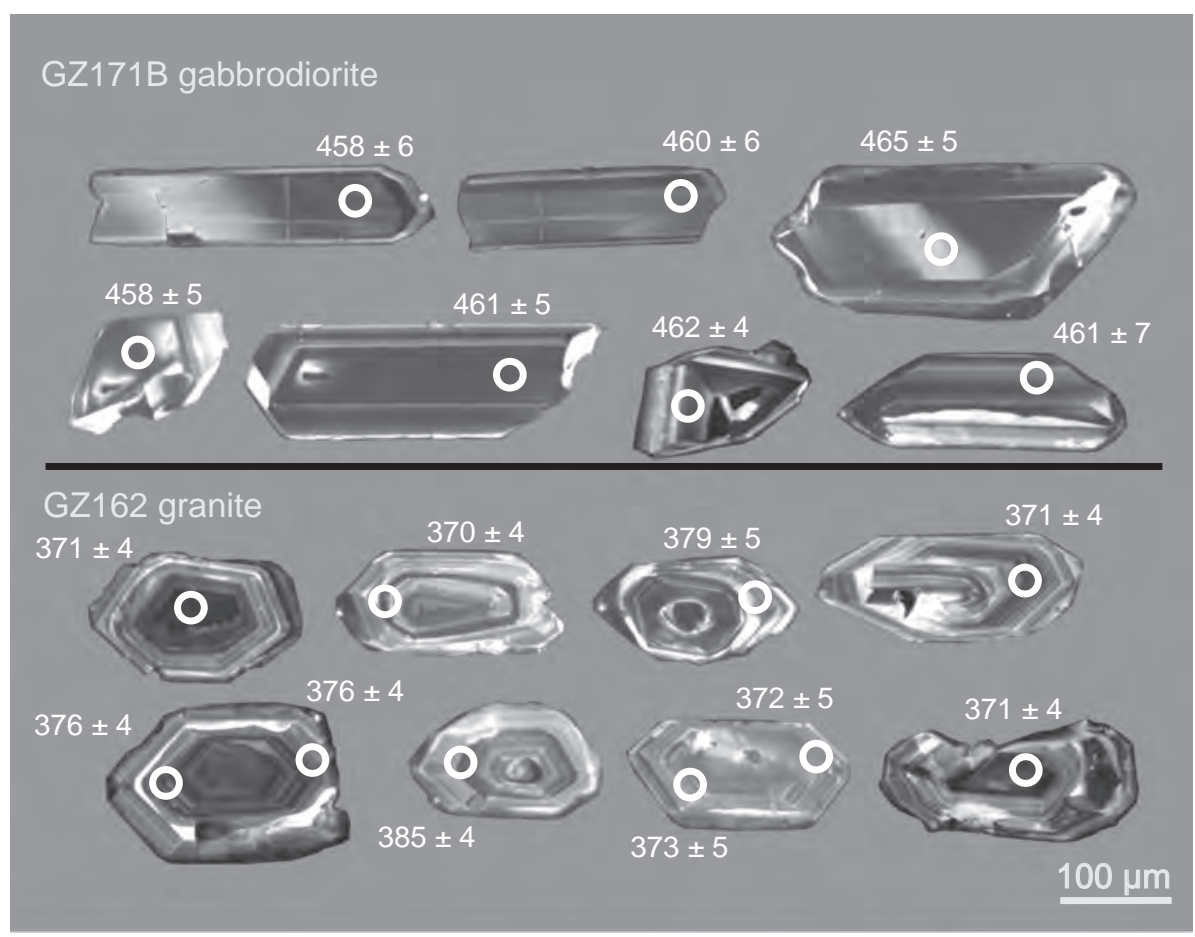

Fig. 9 Representative cathodoluminescence images of the dated zircon grains. Laser-ablation ICP-MS analytical spots are marked by concordant ${ }^{206} \mathrm{~Pb} /{ }^{238} \mathrm{U}$ ages with $1 \sigma$ uncertainties.

topic data for the magmatic arc-related rocks from the Lake Zone of southern and western Mongolia (Kovalenko et al. 2004; Rudnev et al. 2009, 2013; Kovach et al. 2011; Yarmouluk et al. 2011). The U-Pb age of $459 \pm 2$ Ma for zircons from the same sample represents the first available geochronological datum timing the emplacement of the gabbro-diorite suite in the Togtokhinshil Complex. It also provides, to our knowledge first, evidence of the Mid-Ordovician arc-related magmatic activity in the Lake Zone. The obvious lack of zircon inheritance confirms that the magma parental to the gabbrodiorite was derived from hot melt of a juvenile, likely mantle source.

\subsubsection{Granite suite}

Regarding the granite suite, it plots in a field of minimal melts in multicationic $R_{1}-R_{2}$ plot, occupied by anatectic, collision-related associations but into which also converge other granitoids regardless of their tectonic setting (Batchelor and Bowden 1985; Fig. 11a). The position in the discrimination diagrams of Pearce et al. (1984) (not
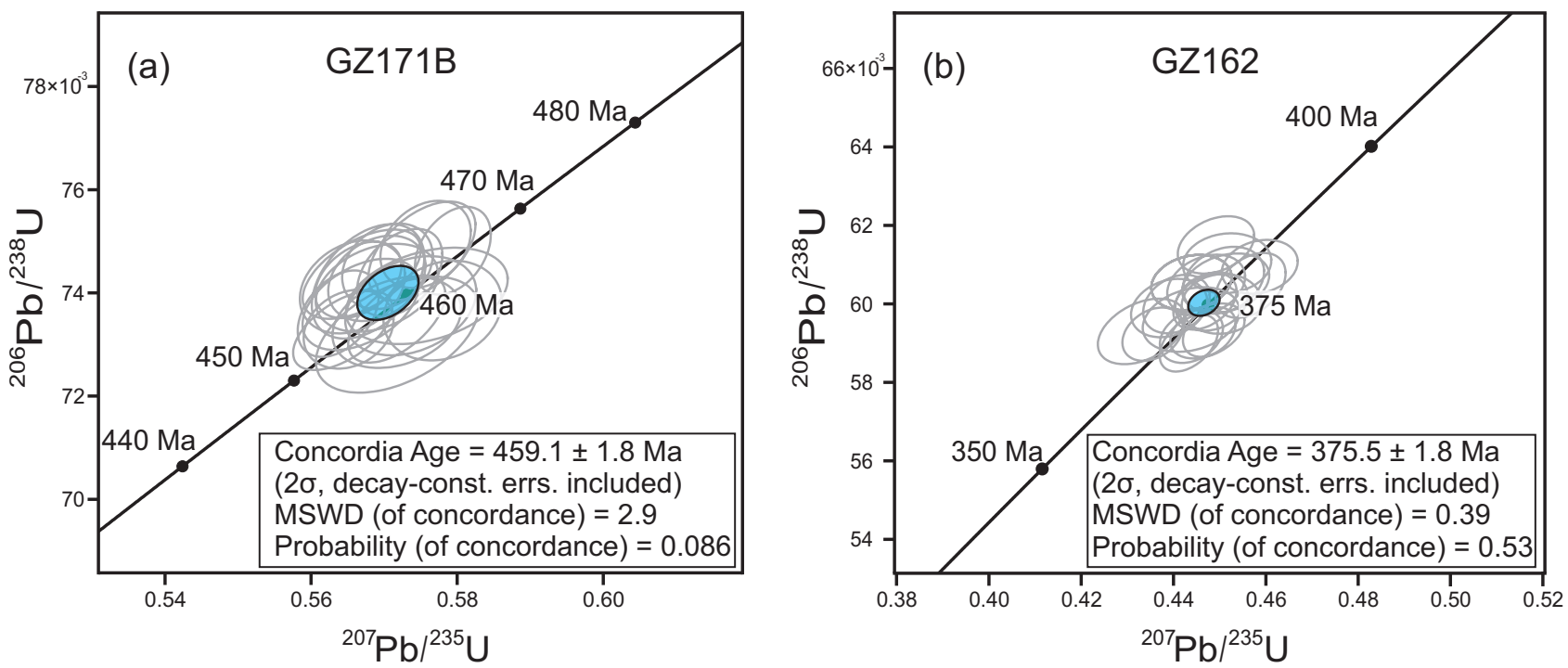

Fig. $10 \mathrm{U}-\mathrm{Pb}$ concordia diagrams and calculated mean concordia zircon ages for magmatic zircons from the studied samples (LA-ICP-MS data). All data are plotted with $2 \sigma$ uncertainties. 
Fig. 11 Geotectonic setting discrimination diagrams for the plutonic rocks of the Togtokhinshil Complex. a-Multi-element $\mathrm{R}_{1}-\mathrm{R}_{2}$ plot (Batchelor and Bowden 1985). b - Ternary diagram Th-Hf/3-Nb/16 of Wood (1980); IAT - island-arc tholeiites; CAB - calc-alkaline basalts; WPT - within-plate tholeiites; WPA - within-plate alkaline basalts. $\mathbf{c}-\mathrm{Nb} / \mathrm{Yb}-\mathrm{Th} / \mathrm{Yb}$ discrimination diagram (Pearce 2008). OIB ocean-island basalts; E- and N-MORB - enriched and normal mid-ocean-ridge basalts. d - Ternary plot Hf-Rb/30-3Ta (Harris et al. 1986) for various tectonic environments in collision zones. VA pre-collisional, volcanic-arc granites; Group 2 - syn-collisional granites; Group 3 - late- or post-collisional calc-alkaline granites; WP - within-plate alkaline granites.
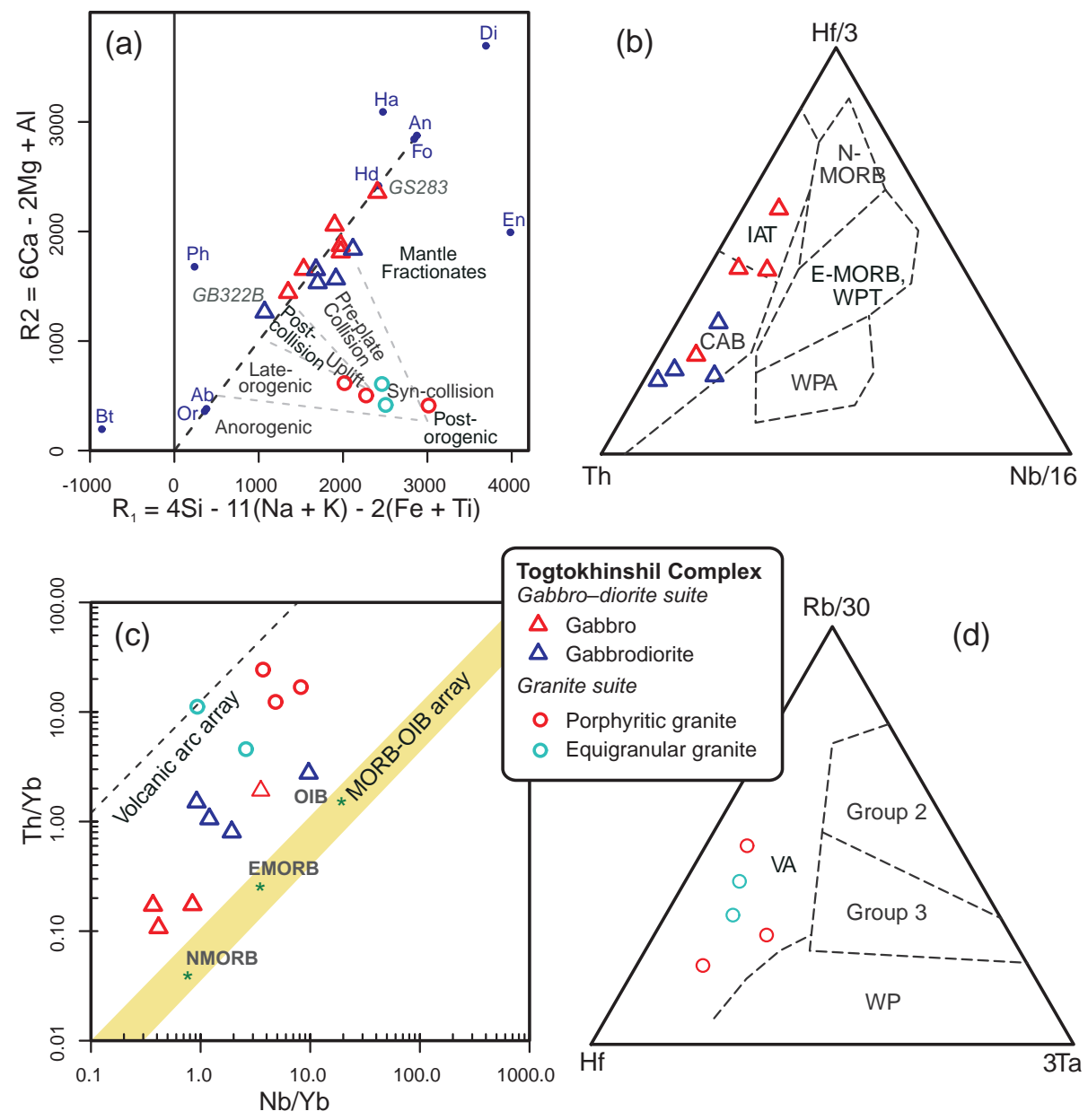

shown) seems to confirm the magmatic-arc affinity of the granite suite. In addition, the ternary plot $\mathrm{Hf}-\mathrm{Rb} / 30-3 \mathrm{Ta}$ of Harris et al. (1986) clearly rules out a syn- or postcollisional origin (Fig. 11d).

However, the lack of associated basic magmatic rocks casts significant doubts on a possible magmatic-arc setting of the granite suite. Moreover, determining the geotectonic setting of the granitic rocks may be equivocal due to potential recycling of older crustal components. Often, the magmatic arc-like signature in granites may be inherited from a source through either remelting of metaigneous, arc-related rocks (Arculus 1987), or anatexis of immature psammitic sediments containing arc-derived detritus (Roberts and Clemens 1993; Janoušek et al. 2010). This holds true especially for the syn-collisional and post-collisional uplift settings, when a range of crustal sources is available for melting (e.g., Pearce et al. 1984; Bonin 1990).

Given the subaluminous character of the granite suite, the parental magmas were likely generated by a partial melting of quartz-feldspathic source (e.g., orthogneiss or metapsammite). These melts could have been subsequently modified by fractional crystallization; the
U-shaped (convex downward) REE patterns with low $\mathrm{Dy} / \mathrm{Yb}$ ratios could reflect amphibole and/or titanite fractionation, or relatively low-P, low-degree partial melting (with Amp-bearing residue) (Davidson et al. 2007; Glazner et al. 2008; Žák et al. 2009). Moreover, an abundance of mafic microgranular enclaves implies also a role for mantle-derived melt in the genesis of the granite suite.

Obtained crystallization age $376 \pm 2$ Ma of zircons from the granite resembles the ages reported from various units in the southern Mongolia (Hrdličková et al. 2008; Yarmolyuk et al. 2008; Demoux et al. 2009; Kröner et al. 2010). Likewise to our granite sample GZ162 $\left(T_{D M}^{N d}=0.78 \mathrm{Ga}\right)$, these Devonian intrusions, sometimes metamorphosed to orthogneisses, have yielded whole-rock Nd and zircon Hf Depleted Mantle model ages of c. $0.8 \mathrm{Ga}$ (Hanžl et al. this volume and references therein).

Similar zircon ages were also found in the granitic and volcanic rocks of the Chinese Altai (Windley et al. 2002; Wang T et al. 2006; Wang Y et al. 2011; Yuan et al. 2007; Sun et al. 2009; Cai et al. 2011) and the Gorny Altai (Glorie et al. 2011; Cai et al. 2014). 


\subsection{Geodynamic implications}

\subsubsection{Gabbro-diorite suite}

The Mongolian tract of the CAOB is mostly interpreted as a mosaic of numerous accreted terranes (Badarch et al. 2002; Xiao et al. 2004; Windley et al. 2007; Kröner et al. 2010). Tectonic collage of the Lake Zone contains several island arc-related complexes distinguished primarily by their geochemical features. The available data imply that the main period of island-arc formation within the Lake Zone between c. 570 to 515 Ma passed into an accretionary stage (Rudnev et al. 2009, 2012, 2013; Kovach et al. 2011; Yarmolyuk et al. 2011). Moreover, Janoušek et al. (2014) and Hanžl et al. (2014) proposed an existence of Cambrian (c. 520-495 Ma) magmatic-arc in the Khantaishir and Zamtyn Nuruu areas (southern part of the Lake Zone). Our study indicates that the magmatic-arc located on the western margin of the Lake Zone was still active at c. $460 \mathrm{Ma}$ and thus (intra-oceanic?) subduction in this branch of the Palaeo-Asian Oceanic system was still ongoing in Ordovician times.

Newly discovered Mid-Ordovician arc-related magmatism and evident difference from the available geochronological data for other arc-related igneous complexes can be explained in two ways. Firstly, position of the Togtokhinshil Complex suggests that it may represent a younger fragment of a huge and persistent magmatic arc situated on the outer (western and southern) margins of the Lake Zone. If having terminated after c. $460 \mathrm{Ma}$, this hypothetical arc would have been active at least c. 55 My longer than thought by other authors (c. 110 My duration?).

Real extent of the intervening oceanic domains and the rate of their closure remain unclear, but the typical life-span of both ancient and modern island-arcs is significantly shorter (c. 60-70 My or less, Paterson and Ducea 2015). However, the life-span and dynamics of some modern island-arcs (e.g., Japanese arc system) (Taira 2001 and references therein) does not exclude the eventuality of the persistent single-arc model.

The second scenario is that several island-arc domains evolved in this region during Early Palaeozoic. Hypothetical, likely subparallel multiple-arc system could have been subsequently merged with the Proterozoic ophiolitic complexes to the east (Zonenshain and Kuzmin 1978; Badarch et al. 2002; Buchan et al. 2002; Matsumoto and Tomurtogoo 2003; Jian et al. 2014), progressively building up the Lake Zone composite domain.

Intense reworking during accretionary processes complicates resolving the single- and multiple-arc models and establishing the arc polarity. Rudnev et al. (2012, 2013) and Yarmolyuk et al. (2011) concluded that the accretion of arc and ophiolites to the easterly Precambrian microcontinent within the Lake Zone terminated at about 480 Ma. Existence of Mid-Ordovician island-arc magmatism (c. $460 \mathrm{Ma}$ ), newly discovered in the Togtokhinshil Complex, indicates that the final stage of accretion in the central part of the Lake Zone took place at least $c$. 20 My later. This fact supports the multiple-arc model mentioned above. Separate arc-belts of various ages were more likely accreted to the consolidated eastern domain successively during the relatively longer period than the single-arc accretion would take. Formation ages for a number of complexes in the Lake Zone are still unknown and without such data a more comprehensive geotectonic model can be hardly formulated. However, the both single- and multiple-arc models are consistent with the anatomy of multiple linear element amalgamation as a basic feature of accretionary orogens summarised by Xiao et al. (2010).

\subsubsection{Granite suite}

The dating of granitic activity in the Togtokhinshil Complex at c. 376 Ma provides a further evidence of the significant Devonian magmatic episode in the region. Unfortunately, its tectonic setting remains uncertain. Another principal question is what the heat source for the extensive crustal anatexis was.

Obvious lack of larger basic magmatic bodies associated with the granite suite is not typical of arc-related plutons. It rather implies that the partial melting could have been induced by syn-collisional crustal thickening. However, there is no evidence for significant crustal thickening in the western part of the Lake Zone and this fact also rules out an idea of lithospheric mantle delamination.

Therefore, the heat source has to be sought in the mantle, and mantle-derived melts have clearly contributed to genesis of the numerous mafic microgranular enclaves enclosed by the granites. The viable possibilities include lithospheric thinning in a back-arc region, or asthenospheric mantle upwelling due to slab break-off or ridge subduction and slab window formation (Davies and von Blanckenburg 1995; Thorkelson 1996; Henk et al. 2000).

The Devonian granitic magmatism was widespread throughout the terranes of the western and the southern Mongolia and the Chinese Altai but different geotectonic settings (including magmatic-arc, back-arc and ridge subduction) were proposed from individual units (e.g., Windley et al. 2002; Wang T et al. 2006; Yuan et al. 2007; Hrdličková at al. 2008; Yarmolyuk et al. 2008; Demoux et al. 2009; Kröner et al 2010; Cai et al. 2011, 2014; Glorie et al. 2011; Hanžl et al. this volume). Broadly similar ages of high-temperature metamorphism were reported 
from high-grade complexes of the Hovd Zone (Soejono et al. 2015), the Tseel Terrane (Kozakov et al. 2009; Windley et al. 2007; Jiang et al. 2012; Burenjargal et al. 2014), the Gobi-Altai Zone (Broussolle et al. 2015) and the Chinese Altai (Sun et al. 2009; Jiang et al. 2010; Cai et al. 2011). Spatial and temporal coincidence of MidLate Devonian magmatic activity and high-temperature metamorphic event in the CAOB could be generally interpreted as a result of a widespread elevated geothermal gradient in the region. The Late Devonian crustal melting in the studied, presumably already amalgamated part of the CAOB was probably caused by the high thermal input from upwelling hot asthenospheric mantle and/or lithospheric thinning. These processes may reflect a farfield subduction.

\section{Conclusions}

Laser-ablation ICP-MS zircon U-Pb dating results and whole-rock geochemical data indicate that magmatic rocks of the Togtokhinshil Complex resulted from two magmatic events.

1) Voluminous magmatic rocks of the gabbro-diorite suite were emplaced at c. $460 \mathrm{Ma}$. The geochemical signatures indicate that the magmas were formed in a magmatic-arc and were derived either exclusively from the mantle source or partly generated by remelting of juvenile mafic crust. These results are the first evidence for a pulse of Mid-Ordovician magmatic arc-related magmatism in the western part of the Lake Zone. The gabbro-diorite suite of the Togtokhinshil Complex probably represents either fragment of a long-lived magmatic-arc that bordered western margin of the Lake Zone, or, more likely, a member of multiple-island arc system within Palaeo-Asian Oceanic domain.

2) Granite suite of the Togtokhinshil Complex (c. 376 $\mathrm{Ma}$ ) represents further evidence of the widespread Late Devonian magmatism in the CAOB. It was most likely a product of mantle heat-induced crustal anataxis. The geodynamic cause for this high-temperature tectono-thermal event is unclear, but may include effects of asthenospheric mantle upwelling and/or lithospheric extension.

Acknowledgements. We gratefully acknowledge B. Batkhishig and an anonymous colleague as well as the handling editor O. Gerel for their constructive reviews which helped to improve the paper. We are indebted to V. Erban for Nd isotopic analyses, P. Gadas and R. Škoda for the electron microprobe analyses, J. Durišová the operating LA-ICP MS, S. Vrána for microscopy and J. Jelének for help in drawing Fig. 1. We thank T. Vorel,
K. Verner, V. Fürych, O. Oyun-Enkh, G. Nyamtsetseg and B. Janzanpagma for invaluable field assistance. This study was supported by the project of the Czech Development Agency "Geological mapping 1:50 000 and assessment of economic potential of selected region in Western Mongolia CzDA-RO-MN-2013-1-32220", by Czech Science Foundation (GACR P210-12-2205 to K. Schulmann) and in part by RVO67985831 institutional support of MS.

Electronic supplementary material. Descriptions of analytical techniques, selected electron microprobe analyses of the main rock-forming minerals, major- and trace-element whole-rock geochemical analyses and laser-ablation ICP-MS U-Pb data are available at the Journal web site (http://dx.doi.org/10.3190/jgeosci.208).

\section{References}

Anderson JL, Smith DR (1995) The effects of temperature and $\mathrm{fO}_{2}$ on the Al-in hornblende barometer. Amer Miner 80: $549-559$

ARCulus RJ (1987) The significance of source versus process in the tectonic controls of magma genesis. J Volcanol Geotherm Res 32: 1-12

BaAtARHuyag A, GANSUKh L (1999) Geological map of the Mongolia on the scale 1:200 000, map sheet L-46-IX. Geological Information Center, MRAM, Ulaanbaatar (in Mongolian)

Badarch G, Dickson Cunningham W, Windley BF (2002) A new terrane subdivision for Mongolia: implications for the Phanerozoic crustal growth of Central Asia. J Asian Earth Sci 21: 87-110

BATCHELOR RA, Bowden P (1985) Petrogenetic interpretation of granitoid rock series using multicationic parameters. Chem Geol 48: 43-55

Bonin B (1990) From orogenic to anorogenic settings: evolution of granitoid suites after a major orogenesis. Geol J 25: 261-270

BOYNTON WV (1984) Cosmochemistry of the rare earth elements: meteorite studies. In: HENDERSON R (ed) Rare Earth Element Geochemistry. Developments in Geochemistry 2. Elsevier, Amsterdam, pp 89-92

Broussolle A, ŠTí́sská P, Lehmann J, Schulmann K, Hacker BR, Holder R, Kylander-Clark RC, Hanžl P, Racek M, Hasalová P, Lexa O, Hrdlč́ová K, Buriánek D (2015) P-T-t-D record of crustal-scale horizontal flow and magma-assisted doming in the SW Mongolian Altai. J Metamorph Geol 33: 359-383

Buchan C, Pfänder J, Kröner A, Brewer TS, Tomurtogoo O, Tomurhuu D, Cunningham D, Windley BF (2002) Timing of accretion and collisional deformation in the Central Asian Orogenic Belt: implications of granite 
geochronology in the Bayankhongor Ophiolite Zone. Chem Geol 192: 23-45

Burenjargal U, Okamoto A, Kunatani T, Sakata S, Hirata T, Tsuchiya N (2014) Thermal evolution of the Tseel Terrane, SW Mongolia and its relation to granitoid intrusions in the Central Asian Orogenic Belt. J Metamorph Geol 32: 765-790

Buriánek D, Janoušek V, Hanžl P, Jiang Y, Schulmann K, Lexa O, Altanbaatar B, Erban V (2016) Petrogenesis of the Late Carboniferous Sagsai Pluton in the SE Mongolian Altai. J Geosci 61: 67-92

Buslov MM, Saphonova I, Watanabe T, Obut O, Fujiwara Y, Iwata K, Semakov NN, Sugai Y, Smirnova LV, KaZanSKY Y (2001) Evolution of the Paleo-Asian Ocean (AltaiSayan Region, Central Asia) and collision of possible Gondwana-derived terranes with the southern marginal part of the Siberian Continent. Geosci J 5: 203-224

Cai K, Sun M, Yuan C, Zhao G, Xiao W, Long X, Wu F (2011) Prolonged magmatism, juvenile nature and tectonic evolution of the Chinese Altai, NW China: evidence from zircon $\mathrm{U}-\mathrm{Pb}$ and $\mathrm{Hf}$ isotopic study of Paleozoic granitoids. J Asian Earth Sci 42: 949-968

Cai K, Sun M, Xiao W, Buslov MM, Yuan C, Zhao G, Long $\mathrm{X}$ (2014) Zircon U-Pb geochronology and Hf isotopic composition of granitoids in Russian Altai Mountain, Central Asian Orogenic Belt. Amer J Sci 314: 580-612

Coleman RG (1994) Reconstruction of the Paleo-Asian Ocean. VSP International Sciences Publisher, Utrecht, The Netherlands, pp 1-177

Cox KG, Bell JD, PANKhurst RJ (1979) The Interpretation of Igneous Rocks. George Allen \& Unwin, London, pp 1-450

Davies JH, von Blanckenburg F (1995) Slab breakoff: a model of lithosphere detachment and its test in the magmatism and deformation of collisional orogens. Earth Planet Sci Lett 129: 85-102

Davidson J, Turner S, Handley H, Macpherson C, Dosseto A (2007) Amphibole "sponge" in arc crust? Geology 35: 787-790

Debon F, Le Fort P (1983) A chemical-mineralogical classification of common plutonic rocks and associations. Trans Roy Soc Edinb, Earth Sci 73: 135-149

Demoux A, Kröner A, Hegner E, Badarch G (2009) Devonian arc-related magmatism in the Tseel Terrane of SW Mongolia: chronological and geochemical evidence. J Geol Soc, London 166: 459-471

Glazner AF, Coleman DS, Bartley JM (2008) The tenuous connection between high-silica rhyolites and granodiorite plutons. Geology 36: 183-186

Glorie S, De Grave J, Buslov MM, Zhimulev Fi, Izmer A, VAndoorne W, Ryabinin A, van den Haute P, Vanhaecke F, Elburg MA (2011) Formation and Palaeozoic evolution of the Gorny-Altai-Altai-Mongolia suture zone (South Siberia): zircon $\mathrm{U} / \mathrm{Pb}$ constraints on the igneous record. Gondwana Res 20: 465-484
Guy A, Schulmann K, Janoušek V, Štípská P, Armstrong R, Belousova E, Dolgopolova A, Seltmann R, Lexa O, JIANG Y, HANŽL P (2015) Geophysical and geochemical nature of relaminated arc-derived lower crust underneath oceanic domain in southern Mongolia. Tectonics 34: 1030-1053

Hanžl P, Buriánek D, Gerdes A, HrdličKová K, Janoušek V, Schulmann K (2014) The Cambrian magmatic activity in the Zamtyn Nuruu range, Mongolian Altai. In: ŹElażniewicz A, Jastrzebski M, Twyrdy M (eds) The 2014 CETEG Conference "Ladek", Proceedings and Excursion Guide. Geol Sudetica 42: 25

Hanžl P, Schulmann K, Janoušek V, Lexa O, HrdličKová K, Jiang Y, Buriánek D, Altanbaatar B, Ganchuluun T, ERBAN V (2016) Making continental crust: origin of Devonian orthogneisses from SE Mongolian Altai. J Geosci 61: 25-50

Harris NBW, Pearce JA, Tindle AG (1986) Geochemical characteristics of collision-zone magmatism. In: CowARD MP, RiEs AC (eds) Collision Tectonics. Geological Society of London Special Publications 19: 67-81

Hastie AR, Kerr AC, Pearce JA, Mitchell SF (2007) Classification of altered volcanic island arc rocks using immobile trace elements: development of the Th-Co discrimination diagram. J Petrol 48: 2341-2357

Henk A, von Blanckenburg F, Finger F, Schaltegger U, ZulAuF G (2000) Syn-convergent high-temperature metamorphism and magmatism in the Variscides: a discussion of potential heat sources. In: FrANKE W, HAAK V, ONCKEN O, TANner D (eds) Orogenic Processes: Quantification and Modelling in the Variscan Belt. Geological Society of London Special Publications 179: 387-399

Holland T, Blundy J (1994) Non-ideal interactions in calcic amphiboles and their bearing on amphibole-plagioclase thermometry. Contrib Mineral Petrol 116: 433-447

Hoskin PWO (2000) Patterns of chaos: fractal statistics and the oscillatory chemistry of zircon. Geochim Cosmochim Acta 64: 1905-1923

Hoskin PWO, Schaltegger U (2003) The composition of zircon and igneous and metamorphic petrogenesis. In: Hanchar JM, Hoskin PWO (eds) Zircon. Mineralogical Society of America and Geochemical Society Reviews in Mineralogy and Geochemistry 53, Washington, 27-62

HrdličKová K, BolormaA K, Buriánek D, HanžL P, Gerdes A, JANOUŠEK V (2008) Petrology and age of metamorphosed rocks in tectonic slices inside the Palaeozoic sediments of the eastern Mongolian Altay, SW Mongolia. J Geosci 53: 139-165

IRvine TN, BARAgAR WR (1971) A guide to the chemical classification of the common igneous rocks. Can J Earth Sci 8: 523-548

JanoušEK V, Konopásek J, Ulrich S, Erban V, TajČmanová L, JEŘÁBEK P (2010) Geochemical character and petrogenesis of Pan-African Amspoort suite of the Boundary 
Igneous Complex in the Kaoko Belt (NW Namibia). Gondwana Res 18: 688-707

Janoušek V, Jiang Y, Schulmann K, Buriánek D, Lexa O, Ganchuluun TBA (2014) The age, nature and likely genesis of the Cambrian Khantaishir arc, Lake Zone. Geophys Res Abstr 16: 6108

Jensen LS (1976) A New Cation Plot for Classifying Subalkalic Volcanic Rocks. Ontario Geological Survey Miscellaneous Papers 66: 1-22

Jian P, Kröner A, Jahn BM, Windley BF, Shi Y, Zhang W, Zhang F, Miao L, Tomurhuu D, Liu D (2014) Zircon dating of Neoproterozoic and Cambrian ophiolites in West Mongolia and implications for the timing of orogenic processes in the central part of the Central Asian Orogenic Belt. Earth Sci Rev 133: 62-93

Jiang Y, Sun M, Zhao G, Yuan C, Xiao W, Xia X, Long X, Wu F (2010) The 2390 Ma high-T metamorphic event in the Chinese Altai: a consequence of ridge-subduction? Amer J Sci 310: 1421-1452

Jiang Y, Sun M, Kröner A, Tumurkhuu D, Long X, Zhao G, Yuan C, XIao WJ (2012) The high-grade Tseel Terrane in SW Mongolia: an Early Paleozoic arc system or a Precambrian sliver? Lithos 142-143: 95-115

Kovach VP, Yarmolyuk VV, Kovalenko VI, Kozlovsky AM, Kotov AB, Terent'eva LB (2011) Composition, sources, and mechanisms of formation of the continental crust of the Lake Zone of the Central Asian Caledonides. II. Geochemical and $\mathrm{Nd}$ isotope data. Petrology 19: 399-425

Kovalenko VI, Yarmolyuk VV, Kovach VP, Kotov AB, Kozakov IK, Salnikova EB, Larin AM (2004) Isotope provinces, mechanisms of generation and sources of the continental crust in the Central Asian mobile belt: geological and isotopic evidence. J Asian Earth Sci 23: 605-627

Kozakov IK, Kovach VP, Bibikova EV, Kirnozova TI, Zagornaya NY, Plotkina YV, Podkovyrov VN (2007) Age and sources of granitoids in the junction zone of the Caledonides and Hercynides in southwestern Mongolia: geodynamic implications. Petrology 15: 126-150

Kozakov IK, Kirnozova TI, Plotkina YV (2009) Age assessments for siliciclastic metasediments of the Bodonchin tectonic sheet, the South Altai metamorphic belt. Stratigr Geol Correl 17: 36-42

Kravchinsky VA, Konstantinov KM, Cogné JP (2001) Palaeomagnetic study of Vendian and Early Cambrian rocks of South Siberia and Central Mongolia: was the Siberian platform assembled at this time? Precambr Res 110: 61-92

Kröner A, Windley BF, Badarch G, Tomurtogoo O, Hegner E, Jahn BM, Gruschia S, Khain EV, Demoux A, Wingate MTD (2007) Accretionary growth and crust formation in the Central Asian Orogenic Belt and comparison with the Arabian-Nubian shield. In: In: HATCHER
Jr. RD, Carlson MP, McBride JH, Martínez Catalán JR (eds) 4-D Framework of Continental Crust. Geological Society of America Memoirs 200: 181-209

Kröner A, Lehmann J, Schulmann K, Demoux A, Lexa O, TomurhuU D, Štípská P, Liu D, Wingate MTD (2010) Lithostratigraphic and geochronological constraints on the evolution of the Central Asian Orogenic Belt in SW Mongolia: Early Paleozoic rifting followed by Late Paleozoic accretion. Amer J Sci 310: 523-574

Leake BE, Woolley AR, Birch WD, Burke EAJ, Ferraris G, Grice JD, Hawthorne FC, Kisch HJ, Krivovichev VG, Schumacher JC, Stephenson NCN, Whittaker EJW (2003) Nomenclature of amphiboles: additions and revisions to the International Mineralogical Association's 1997 recommendations. Canad Mineral 41: 1355-1362

Liew TC, Hofmann AW (1988) Precambrian crustal components, plutonic associations, plate environment of the Hercynian Fold Belt of Central Europe: indications from a Nd and Sr isotopic study. Contrib Mineral Petrol 98: $129-138$

Matsumoto I, Tomurtogoo O (2003) Petrological characteristics of the Hantaishir Ophiolite Complex, Altai region, Mongolia: coexistence of podiform chromitite and boninite. Gondwana Res 6: 161-169

Morimoto N, Fabries J, Ferguson AK, Ginzburg IV, Ross M, Seifert FA, Zussman J, Aoki K, Gottardi G (1988) Nomenclature of pyroxenes. Mineral Mag 52: 535-550

Nissen E, Walker R, Molor E, Fattahi M, Bayasgalan A (2009) Late Quaternary rates of uplift and shortening at Baatar Hyarhan (Mongolian Altai) with optically stimulated luminescence. Geophys J Int 177: 259-278

Paterson SR, Ducea MN (2015) Arc magmatic tempos: gathering the evidence. Elements 11: 91-98

Pearce JA (1982) Trace element characteristics of lavas from destructive plate boundaries. In: THORPE RS (ed) Andesites; Orogenic Andesites and Related Rocks. John Wiley \& Sons, Chichester, pp 525-548

Pearce JA (2008) Geochemical fingerprinting of oceanic basalts with applications to ophiolite classification and the search for Archean oceanic crust. Lithos 100: 14-48

PeArCe JA (2014) Immobile element fingerprinting of ophiolites. Elements 10: 101-108

Pearce JA, Peate DW (1995) Tectonic implications of the composition of volcanic arc magmas. Ann Rev Earth Planet Sci 23: 251-285

Pearce JA, Harris NW, Tindle AG (1984) Trace element discrimination diagrams for the tectonic interpretation of granitic rocks. J Petrol 25: 956-983

Peccerillo A, Taylor SR (1976) Geochemistry of Eocene calc-alkaline volcanic rocks from the Kastamonu area, Northern Turkey. Contrib Mineral Petrol 58: 63-81

Ridolfi F, Renzulli A, Puerini M (2010) Stability and chemical equilibrium of amphibole in calc-alkaline magmas: an overview, new thermobarometric formulations 
and application to subduction related volcanoes. Contrib Mineral Petrol 160: 45-66

Roberts MP, Clemens JD (1993) Origin of high-potassium, calc-alkaline, I-type granitoids. Geology 21: 825-828

Rojas-Agramonte Y, Kröner A, Demoux AD, Xia X, Wang W, Donskaya T, Liu D, Sun M (2011) Detrital and xenocrystic zircon ages from Neoproterozoic to Palaeozoic arc terranes of Mongolia: significance for the origin of crustal fragments in the Central Asian Orogenic Belt. Gondwana Res 19: 751-763

Ruвatтo D (2002) Zircon trace element geochemistry: partitioning with garnet and the link between $\mathrm{U}-\mathrm{Pb}$ ages and metamorphism. Chem Geol 184: 123-138

Rudnev SN, Izokh AE, Kovach VP, Shelepaev RA, TERENT'EVA LB (2009) Age, composition, sources, and geodynamic environments of the origin of granitoids in the northern part of the Ozernaya Zone, western Mongolia: growth mechanisms of the Paleozoic continental crust. Petrology 17: 439-475

Rudnev SN, Izokh AE, Borisenko S, Shelepaev RA, Orihashi Y, Lobanov K, Vishnevsky V (2012) Early Paleozoic magmatism in the Bumbat-Hairhan area of the Lake Zone in western Mongolia (geological, petrochemical, and geochronological data). Russ Geol Geophys 53: 425-441

Rudnev SN, Kovach VP, PonomarchuK VA (2013) VendianEarly Cambrian island-arc plagiogranitoid magmatism in the Altai-Sayan folded area and in the Lake Zone of western Mongolia (geochronological, geochemical, and isotope data). Russ Geol Geophys 54: 1272-1287

Soejono I, Čopjaková R, Čáp P, Buriánek D, Verner K (2015) Lower Palaeozoic tectonometamorphic evolution of the Bij Formation, Hovd Zone, western Mongolia. In: Lexa O, Hasalová P, JeŘÁbek P (eds) CETEG 2015 $13^{\text {th }}$ Meeting of the Central European Tectonic Groups and $20^{\text {th }}$ Meeting of the Czech Tectonic Studies Group (ČTS), Kadaň, 22-25 April, 2015, Abstract Volume. Czech Geological Survey, Prague, pp 82

Sun SS, McDonough WF (1989) Chemical and isotopic systematics of oceanic basalts: implications for mantle composition and processes. In: SAUNDERS AD, Norry M (eds) Magmatism in the Ocean Basins. Geological Society of London Special Publications 42: pp 313-345

Sun M, Long X, Cai K, Jiang Y, Wang B, Yuan CH, Zhao G, XIAO WJ, Wu F (2009) Early Paleozoic ridge subduction in the Chinese Altai: insight from the abrupt change in zircon Hf isotopic compositions. Sci China Ser D 52: $1345-1348$

Şengör A, Natalín B, Burtman V (1993) Evolution of the Altaid tectonic collage and Palaeozoic crustal growth in Eurasia. Nature 364: 299-307

TAIRA A (2001) Tectonic evolution of the Japanese island arc system. Ann Rev Earth Planet Sci 29: 109-134

TAYLOR SR, McLennan SM (1995) The geochemical evolution of the continental crust. Rev Geophys 33: 241-265
THORKELSON DJ (1996) Subduction of diverging plates and the principles of slab window formation. Tectonics 255: 47-63

Tomurtogoo O (1997) A new tectonic scheme of the Paleozoides in Mongolia. Mong Geosc 3: 12-19

Wang T, Hong D, Jahn B, Tong Y, Wang Y, Han B, Wang $X$ (2006) Timing, petrogenesis, and setting of Paleozoic synorogenic intrusions from the Altai Mountains, northwest China: implications for the tectonic evolution of an accretionary orogen. J Geol 114: 735-751

Wang Y, Yuan C, Long X, Sun M, Xiao W, Zhao G, Cai $\mathrm{K}$, JIANG Y (2011) Geochemistry, zircon U-Pb ages and $\mathrm{Hf}$ isotopes of the Paleozoic volcanic rocks in the northwestern Chinese Altai: petrogenesis and tectonic implications. J Asian Earth Sci 42: 969-985

WiLSON M (1989) Igneous Petrogenesis. Unwin Hyman, London, pp 1-466

Windley BF, Kröner A, Guo J, Qu G, Li Y, Zhang C (2002) Neoproterozoic to Paleozoic geology of the Altai Orogen, NW China: new zircon age data and tectonic evolution. J Geol 110: 719-737

Windley BF, Alexeiev DV, Xiao W, Kröner A, Badarch G (2007) Tectonic models for accretion of the Central Asian Orogenic Belt. J Asian Earth Sci 164: 31-47

Wood DA (1980) The application of a Th-Hf-Ta diagram to problems of tectonomagmatic classification and to establishing the nature of crustal contamination of basaltic lavas of the British Tertiary volcanic province. Earth Planet Sci Lett 50: 11-30

Xiao WJ, Windley BF, Badarch G, Sun S, Li J, Qin K, WANG Z (2004) Palaeozoic accretionary and convergent tectonics of the southern Altaids; implications for the growth of Central Asia. J Geol Soc, London 161: 339-342

Xiao WJ, Han C, Yuan C, Sun M, Lin S, Chen H, Li Z, Li J, Sun S (2008) Middle Cambrian to Permian subductionrelated accretionary orogenesis of Northern Xinjiang, NW China: implications for the tectonic evolution of central Asia. J Asian Earth Sci 32: 102-117

Xiao WJ, Huang B, Han C, Sun S, Li J (2010) A review of the western part of the Altaids: a key to understanding the architecture of accretionary orogens. Gondwana Res 18: $253-273$

Yarmolyuk VV, Kovalenko VI, Sal'nikova EB, Kovach VP, Kozlovsky AM, Kotov AB, Lebedev VI (2008) Geochronology of igneous rocks and formation of the Late Paleozoic south Mongolian active margin of the Siberian Continent. Stratigr Geol Correl 16: 162-181

Yarmolyuk VV, Kovach VP, Kovalenko VI, Sal'nikova EB, Kozlovsky AM, Kotov AB, Yakovleva SZ, Fedoseenko AM (2011) Composition, sources, and mechanism of continental crust growth in the Lake Zone of the Central Asian Caledonides: I. Geological and geochronological data. Petrology 19: 55-78 
Yuan C, Sun M, Xiao W, Li X, Chen H, Lin S, Xia X, Long X (2007) Accretionary orogenesis of the Chinese Altai: insights from Paleozoic granitoids. Chem Geol 242: 22-39

Zonenshain LP (1973) The evolution of Central Asiatic geosynclines through sea-floor spreading. Tectonophysics 19: 213-232
Zonenshain LP, KuZmin MI (1978) Khan-Taishir ophiolite complex in western Mongolia and problems of ophiolites. Geotectonics 1: 19-42

ŽÁk J, Paterson SR, Janoušek V, Kabele P (2009) The Mammoth Peak sheeted complex, Tuolumne Batholith, Sierra Nevada, California: a record of initial growth or late thermal contraction in a magma chamber? Contrib Mineral Petrol 158: 447-470 
